\title{
Application Research of Biochar for the Remediation of Soil Heavy Metals Contamination: A Review
}

\author{
Sheng Cheng ${ }^{1,2, \dagger}$, Tao Chen ${ }^{1,2, *, \dagger}$, Wenbin $\mathrm{Xu}^{3}$, Jian Huang ${ }^{1,2}$, Shaojun Jiang ${ }^{1,2}$ and Bo Yan ${ }^{1,2}$ \\ 1 SCNU Environmental Research Institute, Guangdong Provincial Key Laboratory of Chemical Pollution and \\ Environmental Safety \& MOE Key Laboratory of Theoretical Chemistry of Environment, South China \\ Normal University, Guangzhou 510006, China; ShengC@m.scnu.edu.cn (S.C.); 18371807641@163.com (J.H.); \\ shaojunj93@163.com (S.J.); bo.yan@m.scnu.edu.cn (B.Y.) \\ 2 School of Environment, South China Normal University, University Town, Guangzhou 510006, China \\ 3 Dongjiang Environmental Company Limited, Nanshan District, Shenzhen 518057, China; \\ xuwb@dongjiang.com.cn \\ * Correspondence: tao.chen@m.scnu.edn.cn; Tel./Fax: 1379-8199-406 \\ + These authors contributed equally to this work.
}

Academic Editors: Chiara Bisio and Monica Pica

Received: 16 June 2020; Accepted: 8 July 2020; Published: 10 July 2020

\begin{abstract}
Soil contamination by heavy metals threatens the quality of agricultural products and human health, so it is necessary to choose certain economic and effective remediation techniques to control the continuous deterioration of land quality. This paper is intended to present an overview on the application of biochar as an addition to the remediation of heavy-metal-contaminated soil, in terms of its preparation technologies and performance characteristics, remediation mechanisms and effects, and impacts on heavy metal bioavailability. Biochar is a carbon-neutral or carbon-negative product produced by the thermochemical transformation of plant- and animal-based biomass. Biochar shows numerous advantages in increasing soil $\mathrm{pH}$ value and organic carbon content, improving soil water-holding capacity, reducing the available fraction of heavy metals, increasing agricultural crop yield and inhibiting the uptake and accumulation of heavy metals. Different conditions, such as biomass type, pyrolysis temperature, heating rate and residence time are the pivotal factors governing the performance characteristics of biochar. Affected by the $\mathrm{pH}$ value and dissolved organic carbon and ash content of biochar, the interaction mechanisms between biochar and heavy metals mainly includes complexation, reduction, cation exchange, electrostatic attraction and precipitation. Finally, the potential risks of in-situ remediation strategy of biochar are expounded upon, which provides the directions for future research to ensure the safe production and sustainable utilization of biochar.
\end{abstract}

Keywords: biochar; pyrolysis; heavy metals; soil remediation; bioavailability

\section{Introduction}

Soil is the final destination of heavy metals (HMs) whether they are from natural or anthropogenic sources. Mineral resource exploiting and smelting [1], metal electroplating [2], paint and coating processing [3], electronic equipment manufacturing [4], farmland sewage irrigating [5] and pesticide and chemical fertilizer nonstandard applying [6] are the primary anthropogenic activities that aggravate HMs contamination in soil. For instance, more than 30,000 tons of chromium and 800,000 tons of lead have been released into the environment globally in the past half century, most of which eventually accumulates in soils [7]. It is reported that approximately one-sixth of the total agricultural land area in China and about 600,000 hectares of brown field sites in America have been contaminated by HMs [8]. Hitherto, cadmium, lead and arsenic pollution, and associated ecological health risks in southeast China, are more severe than those in northwest China; similarly, those in industrial regions are worse 
than those in agricultural regions [7]. According to the results of a national soil survey [9] in 2014, the over-standard rates of cadmium, mercury, arsenic, copper, lead, chromium, zinc and nickel in soils of China are $7.0 \%, 1.6 \%, 2.7 \%, 2.1 \%, 1.5 \%, 1.1 \%, 0.9 \%$ and $4.8 \%$, respectively. Soil HMs enter the food chain mainly through agricultural crops [10] and ultimately accumulate in organisms through diet, respiratory inhalation, skin contact and other exposure pathways, which directly or indirectly cause serious negative effects on human health [11,12]. The occurrence of cancer villages caused by HMs are the most immediate warning. Soil degradation and reduction of agricultural production land caused by HMs pollution brings an urgent need for the application of various efficient in-situ and ex-situ remediation techniques, to lessen the ecological risk of HMs and maximize the quality and security of agricultural land.

Over recent years, physical remediation (washing, thermal desorption, solidification and guest land methods), chemical remediation (vitrification, leaching, immobilization and electrokinetic methods), and biological remediation (microorganisms and plants) approaches have been applied to achieve this objective [13]. Nevertheless, these methods more or less exist with respective limitations i.e., complicated technique, inefficiency, poor feasibility, short duration, high economic cost, high secondary risk and so on [14]. At present, applying amendments to HM-contaminated soil is considered to be one of the most promising in-situ remediation techniques [15]. The frequently used soil additions include phosphate compounds, liming materials, clay minerals, coal fly ash, organic composts, metal oxides, and biochar $[16,17]$. In brief, the immobilization process of HMs can be achieved mainly through adsorption, complexation, reduction, and precipitation reactions, which cause the redistribution of HMs from soil liquid phases to solid phases, so as to reduce their mobility and bioavailability [16].

Biochar is a kind of carbon-rich, porous substance with abundant active organic functional groups and carbon aromatic structures with a neutral to alkaline $\mathrm{pH}$ value, relatively high cation exchange capacity, large specific surface area, and negative surface charge $[18,19]$. Numerous researchers report that the seed germination [20], plant growth [21-23], crop yields [23,24], and microbial activity and population $[22,25,26]$ have been significantly increased in the HM-contaminated soil amended with biochars. Meanwhile, the effects of biochar on the immobilization/mobilization for different kinds of HMs have been confirmed in many pot experiments and field trials [21,27-29]. Furthermore, the production process of biochar is regarded as an efficient management method to dispose of a large number of organic wastes, which shows certain advantages in economic benefits and feasibility aspects. Remarkably, it cannot be completely ignored that there are still some potential risks in the field application of biochar, and these potential threats may hamper its further application. On this basis, the following aspects of biochar are reviewed: 1) preparation technologies, performance characteristics and influencing factors; 2) interaction mechanisms with different kinds of HMs; 3) effects on plant growth and HM bioavailability; and 4) potential risks in field engineering applications. In addition, the promotion and application of biochar in the future are also discussed.

\section{Preparation of Biochar}

The feedstock for biochar preparation mainly includes wood chips/branches [30-32], agricultural residues [21,33,34] and other woody biomass, as well as animal manure [35-38], sewage sludge [39-41] and other organic wastes. As shown in Table 1, thermochemical conversion technologies involved in the preparation process usually include fast pyrolysis, intermediate pyrolysis, slow pyrolysis, gasification, hydrothermal carbonization, torrefaction, etc. [42,43]. These technologies are mainly classified based on different heating rates, peak temperatures, residence times, reaction atmospheres and other parameters, where biochar, bio-oil and syngas are the main products. The yield of biochar is seriously affected by different operating conditions; several common thermochemical conversion technologies and their approximate product yields are discussed in Table 1. 
Table 1. The reaction conditions and product distribution of various thermochemical conversion technologies.

\begin{tabular}{|c|c|c|c|c|c|c|c|c|}
\hline $\begin{array}{l}\text { Conversion } \\
\text { Technologies }\end{array}$ & Temperature & Heating Rates & Reaction Atmosphere & $\begin{array}{l}\text { Residence } \\
\text { Time }\end{array}$ & Biochar & Bio-Oil & Syngas & Reference \\
\hline Slow pyrolysis & $300-650{ }^{\circ} \mathrm{C}$ & $0.1-1{ }^{\circ} \mathrm{C} \mathrm{s}^{-1}$ & Oxygen-free & $1-24 \mathrm{~h}$ & $25-35 \%$ & $20-30 \%$ & $25-35 \%$ & {$[44,45]$} \\
\hline Intermediate pyrolysis & $\sim 500^{\circ} \mathrm{C}$ & $1.0-10^{\circ} \mathrm{C} \mathrm{s}^{-1}$ & Oxygen-free & $10-20 \mathrm{~s}$ & $20 \%$ & $50 \%$ & $30 \%$ & {$[46,47]$} \\
\hline Gasification & $750-900{ }^{\circ} \mathrm{C}$ & $50-100{ }^{\circ} \mathrm{C} \mathrm{s}^{-1}$ & $\begin{array}{c}\text { Air, steam, } \mathrm{O}_{2}, \mathrm{~N}_{2}, \mathrm{CO}_{2} \text { or } \\
\text { a mixture of these gases }\end{array}$ & $10-20 \mathrm{~s}$ & $10 \%$ & $5 \%$ & $85 \%$ & {$[47,50]$} \\
\hline $\begin{array}{l}\text { Hydrothermal } \\
\text { carbonization }\end{array}$ & $180-300^{\circ} \mathrm{C}$ & $5-10{ }^{\circ} \mathrm{C} \mathrm{min}^{-1}$ & $\begin{array}{c}\text { Confined system with a } \\
\text { pressure of } 2-6 \mathrm{MPa}\end{array}$ & $1-16 \mathrm{~h}$ & $50-80 \%$ & $5-20 \%$ & $2-5 \%$ & {$[19,47]$} \\
\hline
\end{tabular}


Fast pyrolysis can be defined as the thermochemical decomposition process of biomass with low energy density at a moderate pyrolysis temperature in the presence of little or no oxygen. Due to the characteristics of higher heating rate $\left(>200 \mathrm{~K} \mathrm{~min}^{-1}\right)$ and shorter residence time $(<2 \mathrm{~s})$ in this process, bio-oil with high energy density, syngas with relatively low energy density and a small amount of biochar can be obtained (Table 1) [52]. On the contrary, slow pyrolysis is the common type of pyrolysis which is conducive to the formation of biochar rather than the generation of liquid and gaseous products. In this process, the biomass is pyrolyzed in a wide range of carbonization temperature with a heating rate of about $0.1 \sim 1{ }^{\circ} \mathrm{C} \mathrm{s}^{-1}$ for a residence time between few hours and even days [52]. During slow pyrolysis, the fixed carbon content of biochar may increase with the rise of peak temperature, which is particularly prominent in the range of $400 \sim 500^{\circ} \mathrm{C}$ [44]. The operating conditions of intermediate pyrolysis are between fast pyrolysis and slow pyrolysis, which better balances the distribution of solid-liquid product yield. The biochar produced by this pyrolysis mode has a brittle structure and does not contain a high quantity of reactive tar, which is suitable for the application of solid fuel, soil amendments and fertilizer [46].

Gasification is a process of direct contact oxidation of dry biomass with air, steam, oxygen, nitrogen, carbon dioxide or a mixture of these gases [43]. The primary product of gasification is a combustible gas which is packed with $\mathrm{H}_{2}, \mathrm{CO}$ and $\mathrm{CH}_{4}$, while the biochar with low yield contains a high amount of toxic substances such as polyaromatic hydrocarbons, and alkali and alkaline earth metals, that are attributed to the result of high-temperature reactions [51]. Hydrothermal carbonization is performed under a given pressure $(2 \sim 6 \mathrm{MPa})$ and temperature $\left(180 \sim 300^{\circ} \mathrm{C}\right)$ that the feedstocks do not require for drying pretreatment, which is usually some wet biomass or dry biomass mixed with water. Compared to the pyrolysis and gasification processes, hydrothermal carbonization biochar (hydrochar) shows several advantages $[51,53]$. For instance, the hydrochar is characterized by high yield and high purity, and possesses a higher degree of aromatization and more surface functional groups. In addition, hydrochar contains a lower alkali and alkaline earth and heavy metal content, and a higher carbon content and heating value. Torrefaction, also referred to as mild pyrolysis, results in approximately $30 \%$ mass loss of biomass. The main products of torrefaction are organic carbon compounds with high specific energy density, but these cannot be referred to as a "biochar", because torrefaction is just the previous section of the pyrolysis process [43,51]. Consequently, the physicochemical properties of the torrefaction product is between that of biochar and biomass, and it also remains some volatile organic compounds.

Pyrolysis is a conventional process for the preparation of biochar. In this review paper, the properties of pyrolyzed biochar are preliminarily discussed, and the close connection between biochar performance characteristics and biomass feedstock species, pyrolysis temperature and residence time are clarified. According to the above factors (different preparation conditions), the performance characteristics of biochar are reviewed in detail in the next chapter, which provides a theoretical foundation for explaining the interaction mechanisms between biochar and soil HMs.

\section{Performance Characteristics of Biochar}

\subsection{Elemental Composition}

Element composition and content of biochar are a function of biomass species and pyrolysis temperature [54]. Generally, the content of total N, P, K, Ca, Mg and other nutrient elements in biochar prepared from poultry manure is higher than that of woody biomass, while the content of total $\mathrm{C}$ is the opposite [55]. Meanwhile, poultry manure is rich in mineral elements like $\mathrm{K}$ and $\mathrm{P}$, which are important for plant growth, and thus the poultry-manure-derived biochar may be suitable as an ideal soil amendment instead of fertilizer [56].

The rise in pyrolysis temperature of biomass commonly results in the increase of ash and C content of biochar [50,57]. The $\mathrm{N}$ content of lignocellulosic type biochar increased slightly with the rise of pyrolysis temperature [58,59], while that of animal-manure- and sewage-sludge-derived 
biochar shows a downward trend [35,60-62]. Furthermore, the pyrolysis conditions of biomass such as a higher temperature and longer residence time are beneficial to the accumulation of total $\mathrm{P}$ and $\mathrm{K}[50,63]$, the release of $\mathrm{Ca}, \mathrm{Mg}$ and $\mathrm{Si}$, and the retention of $\mathrm{Fe}, \mathrm{Mn}$ and S [47]. Correspondingly, with the increase in reaction time and temperature, other unstable substances (containing $\mathrm{H}$ and $\mathrm{O}$ elements) of biomass are removed by deoxygenation, dehydration and decarboxylation reactions progressively, which leads to the loss of volatile organic compounds and the reduction of $\mathrm{H} / \mathrm{C}-\mathrm{O} / \mathrm{C}$ ratio $[51,57,64,65]$. These results indicate that the high-temperature biochar more easily forms a very stable crystal graphite-like structure and possesses a higher carbonization degree and more aromatic structures [66-68]. For example, Jindo et al. [66] reported that the O/C ratio of biochar pyrolyzed in the temperature range of $400 \sim 500{ }^{\circ} \mathrm{C}$ changed according to the following order: rice straw $>$ rice husk $>$ wood chips of apple tree $>$ wood chips of oak tree. Therefore, these results indicate that there is a higher content of lignin and a slower mineralization rate in woody biomass (i.e., apple tree, oak tree), compared with herbaceous biochar (i.e., rice straw, rice husk) and sewage sludge biochar; furthermore, it has a lower O/C ratio, making woody biochar's structure more stable [67].

\subsection{Functional Groups Abundance}

As mentioned in Section 3.1, a high pyrolysis temperature commonly results in the decrease of the $\mathrm{H} / \mathrm{C}, \mathrm{O} / \mathrm{C}$ and $\mathrm{N} / \mathrm{C}$ ratios in biochar, which immediately indicates the decrease of its abundance of hydroxyl, carboxylic and amino functional groups [18]. Chen et al. [57] summarized the variation of FTIR characterization of pine wood shaving derived biochar with pyrolysis temperature: 1) for $150{ }^{\circ} \mathrm{C}$, biochar is rich in - $\mathrm{OH}$ groups, $\mathrm{CH}_{2}$ units, $\mathrm{C}=\mathrm{O}, \mathrm{C}=\mathrm{C}$, aromatic $\mathrm{CO}-$, and phenolic-OH; 2) for $250^{\circ} \mathrm{C}$, $\mathrm{C}=\mathrm{O}$ and $\mathrm{C}=\mathrm{C}$ stretching vibrations were enhanced; 3 ) for $350^{\circ} \mathrm{C}$, the band $\mathrm{CH}_{2}$ units disappeared completely, and aromatic ring and $\mathrm{C}=\mathrm{C}$ stretching vibration of lignin strengthened; 4) for $500{ }^{\circ} \mathrm{C}$, $\mathrm{C}=\mathrm{O}$ and $\mathrm{C}=\mathrm{C}$ stretching vibrations were significantly weakened; 5) for $700^{\circ} \mathrm{C}$, merely $\mathrm{C}=\mathrm{C}$ of lignin and aromatic $\mathrm{C}-\mathrm{H}$ vibrations were spotted. During the whole heating process, the band $\mathrm{C}-\mathrm{O}-\mathrm{C}$ of cellulose and hemicellulose reduced with the rise of pyrolysis temperature, until it disappeared. Hence, these results show that hemicellulose with short side chains, thermally stable cellulose, and lignin with phenolic structures contained in lignocellulosic are generally decomposed at $200 \sim 350{ }^{\circ} \mathrm{C}, 305 \sim 375{ }^{\circ} \mathrm{C}$ and $250 \sim 500{ }^{\circ} \mathrm{C}$, respectively [69]. In addition, Ding et al. [70] indicated that compared with $250{ }^{\circ} \mathrm{C}$ pyrolyzed sugarcane-derived biochar, $\mathrm{C} \equiv \mathrm{C}$ and $\mathrm{C}=\mathrm{O}$ in $500{ }^{\circ} \mathrm{C}$ pyrolyzed biochar were relatively reduced, while C-O completely disappeared.

Moreover, the abundant surface functional groups such as $\mathrm{C}-\mathrm{O}, \mathrm{C}=\mathrm{O},-\mathrm{COOH}$ and $-\mathrm{OH}$ in biochar possess high modifiability, which is the foundation for the preparation of various functionalized carbon materials [52]. For instance, Yang et al. [71] incubated walnut-shell-derived biochar with $\mathrm{Al}, \mathrm{Ca}, \mathrm{Fe}$ minerals or kaolinite, and the modified biochar's relative content of $\mathrm{C}-\mathrm{C}, \mathrm{C}=\mathrm{C}$ and $\mathrm{C}-\mathrm{H}$ increased from $63.8 \%$ to $72.5 \sim 81.8 \%$, while $\mathrm{C}-\mathrm{O}, \mathrm{C}=\mathrm{O}$, and $-\mathrm{COOH}$ decreased from $36.3 \%$ to $16.6 \sim 26.5 \%$. This result means that the interaction between biochar and minerals ( $\mathrm{Al}, \mathrm{Ca}, \mathrm{Fe}$, or kaolinite) has prevented the oxidation of $\mathrm{C}-\mathrm{C}, \mathrm{C}=\mathrm{C}, \mathrm{C}-\mathrm{H}$ into $\mathrm{C}-\mathrm{O}, \mathrm{C}=\mathrm{O}$ or $-\mathrm{COOH}$, which enhanced the oxidation resistance of biochar surface. This is related to the modification process of biochar, which has been reviewed by previous scholars in the following papers $[18,31,72]$, and will not be further analyzed in this paper.

\subsection{Cation Exchange Capacity (CEC) and Specific Surface Area (SSA)}

With the pyrolysis processes conducting, the SSA (specific surface area) value of biochar has significantly increased compared to the feedstock, while the relatively low temperature pyrolyzed biochar has the highest CEC (cation exchange capacity) value [73]. Although high-temperature biochar cannot possess the highest CEC and SSA values simultaneously, there are adequate functional groups remaining in the biochar structures to provide negative charges. The low $\mathrm{O} / \mathrm{C}$ atomic ratio of high-temperature biochar results in a decrease in the CEC value, which is mainly manifested by the reduction of volatile organic compounds and acidic functional groups [74]. In other words, the high SSA and $\mathrm{pH}$ value of biochar pyrolyzed at higher temperatures $\left(>600^{\circ} \mathrm{C}\right)$ may compensate for 
the low CEC value to supply greater CEC provision to soil [54]. Thereby, biochar is a combination of charged surface functional groups and specific surface area, which can combine with HMs by adsorption and complexation reactions. For example, Yuan et al. [75] raised the pyrolysis temperature of sewage sludge from $300{ }^{\circ} \mathrm{C}$ to $700{ }^{\circ} \mathrm{C}$, and found that the $\mathrm{O} / \mathrm{C}$ ratio of biochar decreased from 0.33 to 0.05 and the volatile matter content reduced from $27.4 \%$ to $5.5 \%$, but the SSA value increased from $14.37 \mathrm{~m}^{2} \mathrm{~g}^{-1}$ to $26.70 \mathrm{~m}^{2} \mathrm{~g}^{-1}$. Similarly, Heitkötter et al. [76] used corn digestate (derived from maize silage) as feedstock, as the temperature increased from $400{ }^{\circ} \mathrm{C}$ to $600{ }^{\circ} \mathrm{C}$, the $\mathrm{CEC}$ value decreased by $29.9 \%$, but the SSA value increased by $50.7 \%$ which exactly made up for the deficiencies in the CEC value reduction. The cation exchange capacity of biochar was enhanced by the tendency of attracting positive charges through its surface functional groups, which is an important feature for the remediation of HM-contaminated soil [77]. Furthermore, the porosity and pore size of biochar still depend on pyrolysis temperature, because the release of volatile organic compounds at higher pyrolysis temperatures may promote the formation of micropores.

\section{4. $\mathrm{pH}$ Value}

The $\mathrm{pH}$ value of biochar is mostly alkaline, and normally increases with the rise of pyrolysis temperature, which means biochar possesses the abilities to improve soil $\mathrm{pH}$ and CEC value, and to reduce soil acidity and bioavailability of certain HMs [78-80]. Fidel et al. [81] summarized four broad categories of biochar alkalinity, including: (1) surface organic functional groups; (2) soluble organic compounds; (3) carbonates/bicarbonates; and (4) other inorganic alkalis such as oxides, hydroxides, sulfates, sulfides, and orthophosphates. Surface organic functional groups have a long-term effect on the amelioration of soil properties (e.g., $\mathrm{pH}$ and CEC value), while soluble organic and inorganic alkalis contribute to the short-term improvement of soil acidification [54,81]. The functional groups separated from the pyrolysis of biomass are predominantly acidic in essence, such as the carboxyl group, hydroxyl group, or formyl group [73]. For others, the alkalinity of remaining solid (includes ash) raised with the increase number of functional groups released by biomass, therefore, the increase of $\mathrm{pH}$ value of biochar is the direct result of the increasing degree of carbonization [73]. The carbonates formed by mineral elements were considered to be the primary alkaline substances in biochar, and especially the biochar pyrolyzed at high temperatures possesses a higher content of carbonates a stronger buffer capacity [80]. Shen et al. [34] reported that the $\mathrm{pH}$ value (7.94) of rice-straw-derived biochar pyrolyzed at $300{ }^{\circ} \mathrm{C}$ is alkalescence, while the biochars with higher $\mathrm{pH}$ values $(10.40$ and 10.68) can be obtained at higher pyrolysis temperatures $\left(500^{\circ} \mathrm{C}\right.$ and $\left.700{ }^{\circ} \mathrm{C}\right)$. The results are attributed to the decomposition of acidic functional groups such as the carboxyl group and phenolic hydroxyl group, and the formation of alkaline minerals like $\mathrm{K}_{2} \mathrm{O}$ in high-temperature pyrolyzed biochar. In addition, there is a high ash content in poultry manure and algae biomass, so the $\mathrm{pH}$ value of biochar pyrolyzed at the same temperature is higher than that of other woody biochar [82]. However, in some studies, the biochar produced by hydrothermal carbonization is typically acidic [83]. For example, the $\mathrm{pH}$ value of Miscanthus-derived hydrochar prepared by Gronwald et al. [84] at $200{ }^{\circ} \mathrm{C}$ is 3.8 , and Cui et al. [85] found that the $\mathrm{pH}$ values of Hydrocotyle verticillata-, Myriophyllum spicatum- and Canna indica-derived hydrochar $\left(200{ }^{\circ} \mathrm{C}\right)$ are $5.07,4.97$ and 6.48. Liu et al. [86] adjusted the $\mathrm{pH}$ value of the initial solution ( $\mathrm{pH}=2,3,5,7,9,11,12)$ of the hydrothermal carbonization process, so that the $\mathrm{pH}$ value of the prepared sewage-sludge-derived hydrochar was still weakly acidic or neutral (corresponding $\mathrm{pH}=5.05,6.11,7.24,6.60,6.62,6.74,6.94)$. The presence of carboxyl functional groups on the surface of hydrochar as a result of formation of acetic and formic acids during the hydrothermal carbonization process could be the reason for the low $\mathrm{pH}$ value [87]. 


\section{Remediation of Soil HMs Contamination by Biochar}

\subsection{Interaction Mechanisms of Biochar and HMs in Soil}

The different sources of biomass feedstocks, and the diverse pyrolysis conditions applied in the preparation processes, lead to various biochar performance characteristics, which may in turn affect the interaction mechanisms between biochar and HMs. On the other hand, the greatest concerns of HMs have been focused on copper, arsenic, cadmium, lead, mercury, and chromium. Table 2 summarizes the research progress on biochar applications for the remediation of HM-contaminated soil, which included different types of biochar, different application conditions, and different HM treatment efficiencies. The various mechanisms proposed for the interaction of biochar with HMs are summarized in Figure 1. It shows that the abundant surface functional groups, mineral substances, alkaline metal ions, $\pi$-electrons, organic matters, and pore structures of micropores provided by biochar are the effective binding sites of HMs. Biochar is able to absorb or combine soil HMs through complexation, reduction, cation exchange, electrostatic attraction, and precipitation functions, or convert HMs from inorganic states into organic states, which changes HM mobility and bioavailability $[14,88,89]$, and then improves soil agronomic benefits. Therefore, the interaction mechanisms between biochar and HMs are critical for the soil remediation and are discussed in detail in the following sections.

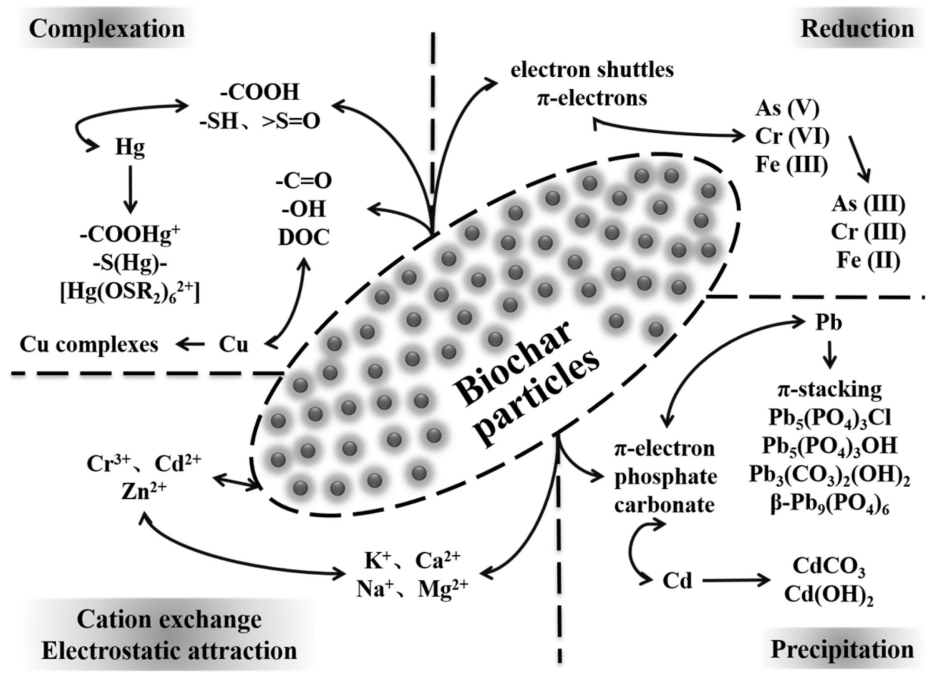

Figure 1. Interaction mechanism between biochar particles and HMs in soil. 
Table 2. Remediation efficiency of biochar on HM (heavy metal)-contaminated soil.

\begin{tabular}{|c|c|c|c|c|c|c|c|c|}
\hline Metals & $\begin{array}{l}\text { Types of Biomass } \\
\text { Feedstock }\end{array}$ & $\begin{array}{c}\text { Pyrolysis } \\
\text { Temperature }\end{array}$ & Dosage & Duration $^{a}$ & Soil Types & $\begin{array}{l}\text { Total Metal } \\
\text { Content }\end{array}$ & $\begin{array}{l}\text { Immobilization Efficiency } \\
\text { (Evaluation Method) }\end{array}$ & Reference \\
\hline \multirow{8}{*}{$\mathrm{Cu}$} & Chicken manure & $500{ }^{\circ} \mathrm{C}$ & $5 \%$ & $14 \mathrm{~d}$ & Sedimentary alfisol & $800 \mathrm{mg} \mathrm{kg}^{-1}$ & $73 \%\left(\mathrm{NH}_{4} \mathrm{NO}_{3}\right.$-extractable) & [36] \\
\hline & Orange bagasse & $500^{\circ} \mathrm{C}$ & $60 \mathrm{tha}^{-1}$ & $24 \mathrm{~m}$ & Fallow field soil & $100 \mathrm{mg} \mathrm{kg}^{-1}$ & $28 \%$ (citric acid-extractable) & [90] \\
\hline & Chicken manure & $550^{\circ} \mathrm{C}$ & $5 \%$ & $14 \mathrm{~d}$ & Mine soil & $1805 \mathrm{mg} \mathrm{kg}^{-1}$ & $79 \%\left(\mathrm{NH}_{4} \mathrm{NO}_{3}\right.$-extractable $)$ & [91] \\
\hline & Orange bagasse & $500^{\circ} \mathrm{C}$ & $60 \mathrm{tha}^{-1}$ & $6 \mathrm{~m}$ & Fallow field soil & $100 \mathrm{mg} \mathrm{kg}^{-1}$ & $41 \%$ (citric acid-extractable) & [92] \\
\hline & Bamboo & $600^{\circ} \mathrm{C}$ & $15 \%$ & $20 \mathrm{~d}$ & Sediment soil & $134.6 \mathrm{mg} \mathrm{kg}^{-1}$ & $79.7 \%$ (HOAc-soluble) & [93] \\
\hline & Oat hull & $300^{\circ} \mathrm{C}$ & $5 \%$ & $24 \mathrm{~m}$ & Sedimentary alfisol & $338 \mathrm{mg} \mathrm{kg}^{-1}$ & $68 \%$ (exchangeable fraction) & [22] \\
\hline & Chicken manure & $550^{\circ} \mathrm{C}$ & $5 \%$ & $14 \mathrm{~d}$ & Hills soil & $160 \mathrm{mg} \mathrm{kg}^{-1}$ & $-45 \%\left(\mathrm{NH}_{4} \mathrm{NO}_{3}\right.$-extractable $)$ & [91] \\
\hline & Sewage sludge & $500^{\circ} \mathrm{C}$ & $30 \mathrm{tha}^{-1}$ & $6 \mathrm{~m}$ & Fallow field soil & $100 \mathrm{mg} \mathrm{kg}^{-1}$ & $-18 \%$ (citric acid-extractable) & [92] \\
\hline \multirow{8}{*}{ As } & Rice straw & $500^{\circ} \mathrm{C}$ & $3 \%$ & $30 \mathrm{~d}$ & Paddy soil & $120 \mathrm{mg} \mathrm{kg}^{-1}$ & $\begin{array}{l}\text { As concentration increased by } 234.5 \% \\
\text { in soil solution }\end{array}$ & [26] \\
\hline & Rice straw & $450^{\circ} \mathrm{C}$ & $1-3 \%$ & $96 \mathrm{~d}$ & Paddy field soil & $212 \mathrm{mg} \mathrm{kg}^{-1}$ & $\begin{array}{c}\text { As concentration increased in } \\
\text { soil porewater }\end{array}$ & [94] \\
\hline & Soybean stover & $700^{\circ} \mathrm{C}$ & $10 \%$ & $90 \mathrm{~d}$ & Agricultural soil & $1945 \mathrm{mg} \mathrm{kg}^{-1}$ & As mobility increased greatly in soil & [25] \\
\hline & Rice straw & $300^{\circ} \mathrm{C}$ & $10 \%$ & $35 \mathrm{~d}$ & Paddy field soil & $92.3 \mathrm{mg} \mathrm{kg}^{-1}$ & $\begin{array}{l}\text { As concentration increased in soil } \\
\text { pore solution }\end{array}$ & [95] \\
\hline & Oil palm fibers & $700^{\circ} \mathrm{C}$ & $3 \%$ & $20 \mathrm{~d}$ & Paddy field soil & $0.3 \mathrm{mg} \mathrm{kg}^{-1}$ & $\begin{array}{c}\text { As concentration increased in } \\
\text { soil solution }\end{array}$ & [96] \\
\hline & Sewage sludge & $200^{\circ} \mathrm{C}$ & $3 \%$ & $6 \mathrm{~d}$ & Agricultural soil & $98.7 \mathrm{mg} \mathrm{kg}^{-1}$ & $-81.9 \%$ (water-soluble) & [97] \\
\hline & Sewage sludge & $350^{\circ} \mathrm{C}$ & $3 \%$ & $6 \mathrm{~d}$ & Agricultural soil & $98.7 \mathrm{mg} \mathrm{kg}^{-1}$ & $\begin{array}{l}42.2 \% \text { (water-soluble) } \\
\text { As(V): } 11.7-28.5 \%\end{array}$ & [97] \\
\hline & Corn straw & $600^{\circ} \mathrm{C}$ & $0.5-2 \%$ & $100 \mathrm{~d}$ & Paddy soil & $73 \mathrm{mg} \mathrm{kg}^{-1}$ & $\begin{array}{c}\text { (phosphate-extractable) } \\
\text { As(III): } 54.0-81.6 \% \\
\text { (phosphate-extractable) }\end{array}$ & [23] \\
\hline \multirow{8}{*}{$\mathrm{Cd}$} & Wheat straw & $350-550^{\circ} \mathrm{C}$ & $40 \mathrm{t} \mathrm{ha}^{-1}$ & $3 y$ & Paddy soil & $5 \mathrm{mg} \mathrm{kg}^{-1}$ & $\begin{array}{l}59 \%\left(\mathrm{CaCl}_{2} \text {-extractable) }\right. \\
24 \% \text { (DTPA-extractable) }\end{array}$ & [98] \\
\hline & Bamboo & $600^{\circ} \mathrm{C}$ & $15 \%$ & $20 \mathrm{~d}$ & Sediment soil & $3.8 \mathrm{mg} \mathrm{kg}^{-1}$ & $31.2 \%$ (HOAc-soluble) & [93] \\
\hline & Soybean straw & $350^{\circ} \mathrm{C}$ & $3 \%$ & $6 \mathrm{~d}$ & Agricultural soil & $1.36 \mathrm{mg} \mathrm{kg}^{-1}$ & $65.7 \%$ (water-soluble) & [97] \\
\hline & Maize straw & $550^{\circ} \mathrm{C}$ & $30 \mathrm{tha}^{-1}$ & $\sim 6 \mathrm{~m}$ & Paddy soil & $2.04 \mathrm{mg} \mathrm{kg}^{-1}$ & 50.4\% (DTPA-extractable) & [29] \\
\hline & Rice straw & $450^{\circ} \mathrm{C}$ & $1-2 \%$ & $96 \mathrm{~d}$ & Paddy field soil & $10.8 \mathrm{mg} \mathrm{kg}^{-1}$ & $\begin{array}{c}\text { Cd concentration decreased in } \\
\text { soil porewater }\end{array}$ & [94] \\
\hline & Sugarcane bagasse & $500{ }^{\circ} \mathrm{C}$ & $1.5 \%$ & $4 \mathrm{~m}$ & Agricultural soil & $50 \mathrm{mg} \mathrm{kg}^{-1}$ & 40.4\% (DTPA-extractable) & [21] \\
\hline & Corn stalk & $550^{\circ} \mathrm{C}$ & $2 \%$ & $30 \mathrm{~d}$ & Arable land soil & $2.0 \mathrm{mg} \mathrm{kg}^{-1}$ & $91 \%\left(\mathrm{CaCl}_{2}\right.$-extractable $)$ & [99] \\
\hline & Hickory nut shell & $500^{\circ} \mathrm{C}$ & $30 \mathrm{tha}^{-1}$ & $\sim 6 \mathrm{~m}$ & Paddy soil & $2.04 \mathrm{mg} \mathrm{kg}^{-1}$ & $53.6 \%$ (DTPA-extractable) & [29] \\
\hline
\end{tabular}


Table 2. Cont.

\begin{tabular}{|c|c|c|c|c|c|c|c|c|}
\hline Metals & $\begin{array}{l}\text { Types of Biomass } \\
\text { Feedstock }\end{array}$ & $\begin{array}{c}\text { Pyrolysis } \\
\text { Temperature }\end{array}$ & Dosage & Duration $^{a}$ & Soil Types & $\begin{array}{l}\text { Total Metal } \\
\text { Content }\end{array}$ & $\begin{array}{l}\text { Immobilization Efficiency } \\
\text { (Evaluation Method) }\end{array}$ & Reference \\
\hline \multirow{6}{*}{$\mathrm{Pb}$} & Soybean stover & $700^{\circ} \mathrm{C}$ & $10 \%$ & $90 \mathrm{~d}$ & Agricultural soil & $1945 \mathrm{mg} \mathrm{kg}^{-1}$ & $\begin{array}{l}95 \%\left(\mathrm{NH}_{4} \mathrm{OAc} \text {-extractable }\right) \\
\text { 95\% (TCLP-extractable) }\end{array}$ & [25] \\
\hline & Vegetable waste & $500^{\circ} \mathrm{C}$ & $5 \%$ & $45 \mathrm{~d}$ & Agricultural soil & $1445 \mathrm{mg} \mathrm{kg}^{-1}$ & $87 \%\left(\mathrm{NH}_{4} \mathrm{OAc}-\mathrm{extractable}\right)$ & [100] \\
\hline & Bamboo sawdust & $600^{\circ} \mathrm{C}$ & $37.5 \%$ & $30 \mathrm{~d}$ & Sediment soil & $589.7 \mathrm{mg} \mathrm{kg}^{-1}$ & 100\% (TCLP-extractable) & [101] \\
\hline & Red pepper stalk & $650^{\circ} \mathrm{C}$ & $2.5 \%$ & $45 \mathrm{~d}$ & Agricultural soil & $1445 \mathrm{mg} \mathrm{kg}^{-1}$ & $65 \%\left(\mathrm{NH}_{4} \mathrm{OAc}\right.$-extractable $)$ & [100] \\
\hline & Wheat straw & $350-550{ }^{\circ} \mathrm{C}$ & 40 tha $^{-1}$ & $3 y$ & Paddy soil & $100 \mathrm{mg} \mathrm{kg}^{-1}$ & $\begin{array}{l}59 \%\left(\mathrm{CaCl}_{2} \text {-extractable) }\right. \\
27 \% \text { (DTPA-extractable) }\end{array}$ & [98] \\
\hline & Bamboo & $600^{\circ} \mathrm{C}$ & $15 \%$ & $20 \mathrm{~d}$ & Sediment soil & $44.3 \mathrm{mg} \mathrm{kg}^{-1}$ & 73.2\% (HOAc-soluble) & [93] \\
\hline \multirow{5}{*}{$\mathrm{Hg}$} & Rice husk & $550^{\circ} \mathrm{C}$ & $1-5 \%$ & $10 \mathrm{~d}$ & Field soil & $1000 \mathrm{mg} \mathrm{kg}^{-1}$ & $>94 \%$ (TCLP-extractable) & [102] \\
\hline & Rice hull & $480-660^{\circ} \mathrm{C}$ & $24 \mathrm{tha}^{-1}$ & $118 \mathrm{~d}$ & Farmland soil & $129 \mathrm{mg} \mathrm{kg}^{-1}$ & $\begin{array}{l}\mathrm{Hg} \text { concentration decreased by } 44 \% \text { in } \\
\text { soil porewater }\end{array}$ & [28] \\
\hline & Wheat straw & $350-450^{\circ} \mathrm{C}$ & $72 \mathrm{t} \mathrm{ha}^{-1}$ & $118 \mathrm{~d}$ & Farmland soil & $129 \mathrm{mg} \mathrm{kg}^{-1}$ & $\begin{array}{l}\mathrm{Hg} \text { concentration decreased by } 26 \% \text { in } \\
\text { soil porewater }\end{array}$ & [28] \\
\hline & Sewage sludge & $600^{\circ} \mathrm{C}$ & $5 \%$ & $17 \mathrm{w}$ & Paddy field soil & $2.1 \mathrm{mg} \mathrm{kg}^{-1}$ & $\begin{array}{c}\text { MeHg concentration increased by } 67 \% \\
\text { in soil }\end{array}$ & [41] \\
\hline & Sewage sludge & $600{ }^{\circ} \mathrm{C}$ & $5 \%$ & $17 \mathrm{w}$ & Paddy field soil & $65.3 \mathrm{mg} \mathrm{kg}^{-1}$ & $\begin{array}{c}\text { MeHg concentration increased by } 29 \% \\
\text { in soil }\end{array}$ & [41] \\
\hline \multirow{4}{*}{$\mathrm{Cr}$} & Waste wood & $900^{\circ} \mathrm{C}$ & $1-5 \%$ & $11 \mathrm{w}$ & Tannery waste soil & $12285 \mathrm{mg} \mathrm{kg}^{-1}$ & $28-68 \%\left(\mathrm{CaCl}_{2}\right.$-extractable $)$ & [103] \\
\hline & Sugarcane bagasse & $500^{\circ} \mathrm{C}$ & $1.5 \%$ & $4 \mathrm{~m}$ & Agricultural soil & $50 \mathrm{mg} \mathrm{kg}^{-1}$ & $\begin{array}{c}49.6 \% \text { (DTPA-extractable) } \\
\text { Cr(total): } 48.1 \%\end{array}$ & [21] \\
\hline & Rice straw & $500^{\circ} \mathrm{C}$ & $40 \mathrm{tha}^{-1}$ & $\sim 4 \mathrm{~m}$ & Paddy field soil & $432.8 \mathrm{mg} \mathrm{kg}^{-1}$ & $\begin{array}{c}\left(\mathrm{HNO}_{3} / \mathrm{H}_{2} \mathrm{SO}_{4} \text {-extractable }\right) \\
\mathrm{Cr}(\mathrm{VI}): 22.3 \% \\
\left(\mathrm{HNO}_{3} / \mathrm{H}_{2} \mathrm{SO}_{4} \text {-extractable }\right)\end{array}$ & [104] \\
\hline & Wheat straw & $600^{\circ} \mathrm{C}$ & $0.25 \%$ & $180 \mathrm{~d}$ & Cr-spiked soil & $308 \mathrm{mg} \mathrm{kg}^{-1}$ & $\begin{array}{l}\mathrm{Cr}(\mathrm{VI}): 47.1 \% \text { (TCLP-extractable) } \\
\mathrm{Cr}(\mathrm{VI}): 65.5 \%\left(\mathrm{CaCl}_{2} \text {-extractable) }\right.\end{array}$ & [105] \\
\hline
\end{tabular}

${ }^{\mathrm{a}}$ Units explanation: $\mathrm{d}$ for days, $\mathrm{w}$ for weeks, $\mathrm{m}$ for months and $\mathrm{y}$ for years 


\subsubsection{Copper $(\mathrm{Cu})$}

As described by Meier et al. [36], the functional groups (especially for -OH) and negative $\zeta$-potential existing in chicken-manure-derived biochar has been proved with high affinity for $\mathrm{Cu}$. The immobilization process of $\mathrm{Cu}$ is achieved by increasing soil $\mathrm{pH}$ value and inducing the liming effect, to stimulate the complexation of $\mathrm{Cu}$ (II) with biochar surface functional groups (e.g., $\mathrm{C}=\mathrm{O}$ and phenolic-OH). Additionally, Rechberger et al. [30] found that carbonates and hydroxides in the ash of woodchip-derived biochar are the important adsorbents for $\mathrm{Cu}(\mathrm{II})$, which are able to promote the formation of $\mathrm{CuCO}_{3}$ and $\mathrm{Cu}(\mathrm{OH})_{2}$, and this is also illustrated by the bamboo-derived biochar prepared by Zhang et al. [93]. Therefore, the essential point of $\mathrm{Cu}$ immobilization is to use the alkalinity of biochar to improve soil $\mathrm{pH}$ value [92]. On the other side of the shield, the mobility of $\mathrm{Cu}$ is highly affected by the content of soil-dissolved organic carbon (DOC). For instance, Park et al. [91] introduced chicken-manure-derived biochar to Cu-spiked soil, which led to the increase of soil DOC content and provoked the conversion of $\mathrm{Cu}$ (II) into $\mathrm{Cu}$ complexes with higher solubility. Wagner et al. [106] also reported that the Miscanthus-derived biochar can increase the $\mathrm{Cu}$ concentration in soil solution. In other words, the increase of $\mathrm{Cu}$ concentration in soil pore water is the proximate consequence of the $\mathrm{Cu}$ (II) desorption from soil with the form of organic complex. Hence, the immobilization/mobilization of $\mathrm{Cu}$ by biochar should be further studied according to the actual types of biochar.

\subsubsection{Arsenic (As)}

Phosphorus (P) and As have similar chemical properties and the soil $\mathrm{P}$ content is a critical factor in controlling the mobility of As [25]. There is a significant positive correlation between phosphate content and arsenate content in As-contaminated soils. After the soils are treated with P-containing biochar, the competition between soluble phosphate and arsenate that occurred on the adsorption sites of soil particles promoted the desorption of As from soil solid phase, and increased the As concentration in pore water [45], such as soybean-stover-, pine-needle- [25], and rice-straw-derived biochar [94]. The role of soil DOC is similar to P [95], but DOC has another effect. For example, Wang et al. [26] indicated that the application of rice-straw-derived biochar under the anaerobic conditions increased the abundance of Fe-reducing bacteria (e.g., Clostridum, Bacillus and Caloramator) in paddy soil, promoted the reduction of $\mathrm{As}(\mathrm{V})$ adsorbed on the amorphous $\mathrm{Fe} / \mathrm{Al}$ oxides. To be brief, the increase of DOC content in soils enhanced the microbial reduction effect of $\mathrm{As}(\mathrm{V})$, and finally stimulated the release of As (III) from paddy soil. Under the anoxic conditions, similar results were obtained in the application of oil palm fiber derived biochar prepared by Qiao et al. [96]. Biochar, with high aromaticity and alkalinity, and which can act as an electron shuttle, likes humus to promote the microbial reduction of Fe(III) and $\mathrm{As}(\mathrm{V})$ simultaneously [26,96]. In addition, Choppala et al. [27] reported that the $\pi$-electrons provided by the functional groups on the surface of chicken-manure-derived biochar could promote the reduction of $\mathrm{As}(\mathrm{V})$, which is another important factor to enhance the mobility of As. However, the Fe-biochar prepared by Yin et al. [94] and Mn-biochar prepared by Yu et al. [23] are able to adsorb As to the Fe/Mn oxides of biochar surface, thus commendably limiting the migration of As into soil solution, which proved the effectiveness of As immobilization by the modified biochar (not listed in Table 2).

\subsubsection{Cadmium $(\mathrm{Cd})$}

The activity of $\mathrm{Cd}$ in soils strongly depends on soil $\mathrm{pH}$ value [99]. The alkaline substances such as $\mathrm{CO}_{3}{ }^{2-}, \mathrm{PO}_{4}{ }^{3-}$ and $\mathrm{OH}^{-}$contained in biochar commonly have strong adsorption and binding capacity to $\mathrm{Cd}$ in soils, which makes the free $\mathrm{Cd}(\mathrm{II})$ transform into $\mathrm{Cd}(\mathrm{OH})_{2}, \mathrm{Cd}_{3}\left(\mathrm{PO}_{4}\right)_{2}$ and $\mathrm{CdCO}_{3}$ precipitates [30]. The high adsorption affinity produced by the cation exchange effects of soil calcite $\left(\mathrm{CaCO}_{3}\right)$ with $\mathrm{Cd}(\mathrm{II})$ is the main factor to reduce the bioavailability of $\mathrm{Cd}$; of course, the abundant functional groups and large specific surface area in biochar are also critical for Cd immobilization [29]. For instance, Yin et al. [94] used 1 2\% rice-straw-derived biochar to treat farmland soil in a mining 
area, and found that the $\mathrm{Cd}$ concentration in pore water of soil rhizosphere was significantly reduced, and the corn-straw-derived biochar prepared by Gao et al. [99] decreased $91 \%$ of the $\mathrm{CaCl}_{2}$-extractable $\mathrm{Cd}$ content in the farmland soil. Besides, Bian et al. [98] applied $40 \mathrm{t} \mathrm{ha}^{-1}$ wheat-straw-derived biochar to paddy soil, and the $\mathrm{CaCl}_{2}$-extractable $\mathrm{Cd}$ and DTPA-extractable $\mathrm{Cd}$ was reduced by $59 \%$ and $24 \%$, respectively, over the past three years. Thereby, the result of biochar in increasing soil $\mathrm{pH}$ value is extremely effective for the immobilization of $\mathrm{Cd}$. It is worth mentioning that the basic substances in biochar can also stimulate the deprotonation of acid functional groups of biochar, and further enhance the adsorption capacity of Cd [107].

\subsubsection{Lead $(\mathrm{Pb})$}

The immobilization process of $\mathrm{Pb}$ in soils by biochar is relatively simple. For example, Ahmad et al. [25] considered that the immobilization process of $\mathrm{Pb}$ stimulated by soybean-stover -derived biochar is attributed to the $\pi$-cation electron donor-acceptor interaction, which occurs by the $\pi$-electron-rich biochar graphene surface and $\pi$-electron-deficient positively charged $\mathrm{Pb}$ (II) ion. Furthermore, the cation exchange and precipitation reactions between basic substances $\left(\mathrm{CO}_{3}{ }^{2-}\right.$, $\mathrm{OH}^{-}$and other alkaline earth $\mathrm{Ca}^{2+}, \mathrm{Mg}^{2+}$ ) in biochar and $\mathrm{Pb}$ (II) are able to achieve a significant immobilization effect of $\mathrm{Pb}$, such as the formation of $\mathrm{Pb}_{3}\left(\mathrm{CO}_{3}\right)_{2}(\mathrm{OH})_{2}$ precipitation. In particular, the poultry-manure-derived biochar [38] and the sewage-sludge-derived biochar [39] contain abundant phosphates, which are able to form insoluble compounds, such as $\mathrm{Pb}_{5}\left(\mathrm{PO}_{4}\right)_{3} \mathrm{Cl}, \mathrm{Pb}_{5}\left(\mathrm{PO}_{4}\right)_{3} \mathrm{OH}$ and $\beta-\mathrm{Pb}_{9}\left(\mathrm{PO}_{4}\right)_{6}$, with $\mathrm{Pb}(\mathrm{II})$ to reduce the mobility of $\mathrm{Pb}[25,101]$. The functional groups also have certain effects on the immobilization of $\mathrm{Pb}$. Igalavithana et al. [100] reported that the vegetable-waste-derived biochar not only improved soil $\mathrm{pH}$ value, but also promoted the immobilization of $\mathrm{Pb}$ by the strong covalent bonding action of $\mathrm{N}$-containing functional groups (especially for $-\mathrm{NH}_{2}$ ) on the biochar surface, thereby effectively decreasing the concentration of $\mathrm{NH}_{4} \mathrm{OAc}$-extractable $\mathrm{Pb}$.

\subsubsection{Mercury $(\mathrm{Hg})$}

$\mathrm{Hg}$, as a special metal, has great toxicity in soil, but biochar is an effective tool for soil remediation. As Wang et al. [31] remarked, the carboxyl group in a hardwood-derived biochar surface and soil $\mathrm{Hg}$ (II) ion develop a coordination reaction generating a complex of $-\mathrm{COOHg}^{+}$precipitate, thereby reducing the mobility of $\mathrm{Hg}$ and the thiol functionalities and sulfoxide groups are also able to react with $\mathrm{Hg}$ (II) ion to form -S(Hg)- and $\left[\mathrm{Hg}\left(\mathrm{OSR}_{2}\right)_{6}{ }^{2+}\right]$ precipitates. Additionally, Xing et al. [28] found that rice-husk-derived biochar possesses a higher sulfate concentration compared with wheat-straw-derived biochar, which is more effective to promote the mercury-sulfur coordination reaction and to produce sulfides precipitation. It is extremely important to know that methylation of $\mathrm{Hg}$ is a special environmental biogeochemical behavior, and once the inorganic-Hg in soils is converted into methylmercury $(\mathrm{MeHg})$, its toxicity and bioaccumulation will be enormously enhanced [108]. The release of rice root exudates reduced soil $\mathrm{pH}$ value, thereby enhancing the methylation of $\mathrm{Hg}$, while the application of alkaline biochar increases soil $\mathrm{pH}$ value and effectively inhibits methylation. Zhang et al. [41] reported that sewage-sludge-derived biochar with high organic matter content can stimulate the growth and activity of heterotrophic microorganisms in $\mathrm{Hg}$-contaminated acidic farmland soil, thus promoting the formation of $\mathrm{MeHg}$. However, the utilization rate of $\mathrm{MeHg}$ in rice has been significantly decreased, which led to the inhibition of $\mathrm{MeHg}$ accumulation in rice and effectively reduced the bioavailability of organic-Hg [41].

\subsubsection{Chromium (Cr)}

Firstly, it should be pointed out that $\mathrm{Cr}$ exists in soils in the form of two valence states, namely $\mathrm{Cr}(\mathrm{VI})$ and $\mathrm{Cr}(\mathrm{III})$. Therefore, the immobilization of $\mathrm{Cr}$ in soils is a complicated combination process of adsorption-reduction-precipitation. The interaction mechanism between biochar and $\mathrm{Cr}$ is mainly manifested in the surface adsorption effect of $\mathrm{Cr}(\mathrm{VI})$ by the oxygen-containing functional groups such as $\mathrm{C}-\mathrm{O}, \mathrm{C}=\mathrm{O},-\mathrm{COOH}$ and $-\mathrm{OH}$ in biochar, as well as the reduction reaction of electrons provided by 
biochar [105]. Specifically, biochar transforms $\mathrm{Cr}(\mathrm{VI})$ into $\mathrm{Cr}$ (III) with lower toxicity and solubility by adsorption-reduction effects, and participates in the formation of $\mathrm{Cr}_{2} \mathrm{O}_{3}$ and/or $\mathrm{Cr}(\mathrm{OH})_{3}$ precipitation, so as to achieve the purpose of $\mathrm{Cr}$ immobilization [109,110]. On the other hand, Choppala et al. [27] applied chicken-manure-derived biochar to Cr-spiked soil with low organic matter content, which significantly increased the supply of soil organic carbon and nutrients, enhancing the soil respiration and microbial activity effectively and finally showing a superior microbial $\mathrm{Cr}(\mathrm{VI})$ reduction effect and reduced the Cr biotoxicity. Moreover, Mandal et al. [111] found that the $\mathrm{Cr}(\mathrm{VI})$ reduction effect of animal-manure-derived biochar in acidic soil was significantly higher than that in alkaline soil.

In summary, many HMs can be continuously immobilized in soil by biochar through specific or non-specific surface adsorption. It is noteworthy that not only the activity of $\mathrm{Cu}$ and As are affected by $\mathrm{DOC}$ content in soil, but also $\mathrm{Pb}$ and $\mathrm{Cd}$. This phenomenon is attributed to the fact that the high-dose application of biochar in soil results in the sharp increase of DOC content, which leads to the complexation of $\mathrm{Pb}$ and $\mathrm{Cd}$ with $\mathrm{DOC}$, and finally increases the mobility and bioavailability of $\mathrm{Pb}$ and $\mathrm{Cd}$. In addition, the adsorption and cation exchange reactions between $\mathrm{HMs}$ and biochar ash (e.g., $\mathrm{K}^{+}$, $\mathrm{Na}^{+}, \mathrm{Ca}^{2+}, \mathrm{Mg}^{2+}$ and other alkali metal ions) are also important factors for the immobilization of HMs.

\subsection{Effect of Biochar on Bioavailability of HMs in Soil}

Plants mainly absorb, transport, and accumulate HMs from contaminated soil by roots. Thus, the primary objectives of biochar soil remediation are limiting the migration and transformation rates of HMs in soil and reducing their bioavailability, so as to prevent HMs from entering organisms through the food chain and to eliminate their toxic effects. The ultimate goal of HM-contaminated soils remediation is to increase crop yields on the premise of ensuring food production safety.

On the one hand, the introduction of biochar provides a source of organic matter, $\mathrm{N}, \mathrm{P}, \mathrm{K}, \mathrm{Ca}, \mathrm{Mg}$ and other nutrients to the soil, which enhances soil enzyme and microbial activities. On the other hand, the plant root environment, soil water retention and saturated hydraulic conductivity [112] can be improved with the presence of biochar, and plant growth and nutrient absorption can be promoted. Finally, it increases the plants biomass, and dilutes the content of HMs in plant tissues to reduce their phytotoxicity. Meier et al. [36] indicated that 5\% chicken-manure-derived biochar can reduce the uptake of $\mathrm{Cu}$ from $66.9 \mathrm{mg} \mathrm{kg}^{-1}$ to $36.6 \mathrm{mg} \mathrm{kg}^{-1}$ in the aboveground part of Oenothera picensis plants in copper-mine-polluted soil, and increase the biomass of shoots and roots by 3.5 times and 3.1 times respectively. Xing et al. [28] reported that after applying $24 \mathrm{t} \mathrm{ha}^{-1}$ and $72 \mathrm{t} \mathrm{ha} \mathrm{a}^{-1}$ rice-husk-derived biochar to mercury-contaminated farmland soils, the $\mathrm{Hg}$ content in rice grains reduced to $10 \mathrm{ng} \mathrm{g}^{-1}$ and $7.2 \mathrm{ng} \mathrm{g}^{-1}$, which significantly inhibited the transportation of $\mathrm{Hg}$ from soil to rice grains, and successfully reached the national standard (below $20 \mathrm{ng} \mathrm{g}^{-1}$ ). Similarly, Li et al. [97] applied $3 \%$ of soybean-straw-derived biochar (hydrothermal carbon at $350^{\circ} \mathrm{C}$ ) to the arsenic and cadmium co-contaminated farmland soil, which reduced the bioaccumulation of As in rice plants by $88 \%$. Besides, compared with the control group, As(III) content decreased from $3.47 \mathrm{mg} \mathrm{kg}^{-1}$ to $0.29 \mathrm{mg}$ $\mathrm{kg}^{-1}, \mathrm{As}(\mathrm{V})$ decreased from $715 \mu \mathrm{g} \mathrm{kg}^{-1}$ to $150 \mu \mathrm{g} \mathrm{kg}^{-1}$, and the treatment effects on Cd were similar [97]. As for cadmium, a field trial studied by Zheng et al. [113] showed that, when the application rates of soybean-straw-derived biochar and rice-straw-derived biochar were $20 \mathrm{t} \mathrm{ha}^{-1}$, the content of $\mathrm{Cd}$ in rice roots, rice shoots, rice husks and rice grains decreased by $25.0 \sim 44.1 \%$ and $19.9 \sim 44.2 \%$, and $46.2 \% \sim 70.6 \%$ and $25.8 \% \sim 70.9 \%$, respectively. Furthermore, the effectiveness of rice-straw-derived biochar in reducing $\mathrm{Cd}$ accumulation in rice grains was also confirmed in the long-term field effects studied by Zhang et al. [29]. Cd contamination of farmland soil is particularly prominent in China, but it happens that China is a large agricultural country, which has a large output of agricultural waste with low cost. Considering the economic value of biochar application, using rice straw, wheat straw and other agricultural wastes to produce biochar and returning it to the field is the best choice.

In a word, the immobilization effects of soil HMs, the limitation of HM uptake and accumulation by plants, the enhancement of plant biomass, and the dilution effect of HMs in plant tissues are the four pivotal performances of biochar to reduce the bioavailability of HMs [114,115]. Although certain 
HMs can be combined with soil DOC and converted into organic complex forms, which are activated finally, these organic complexes commonly possess stability and are not readily or directly absorbed by plants, which has little impact on HM content in plant tissues.

\section{Potential Risks}

Applying biochar as an addition to soil in-situ remediation should not only consider the HM immobilization/mobilization effects, but also take into account the long-term stability and potential ecological risks of biochar, which similarly depend on the type and performance characteristics of biochar. Figure 2 briefly introduced the advantages and disadvantages of biochar in the remediation of soil HM contamination. Firstly, it is reported that biochar may be the carrier of HMs [116], volatile organic compounds (VOCs) [117], dioxin (PCDD/Fs) and polycyclic aromatic hydrocarbons (PAHs) [118,119] and other toxic substances, and the demands for remediation of HM contamination in soil varies from 1.5 to $72 \mathrm{t} \mathrm{ha}^{-1}$ or even higher $[24,28,98,113]$. Therefore, the toxic substances may be released into the soil/air/water environment with the application of the double-edged biochar, which will pose a secondary pollution and ecological risk. So far, from the perspective of soil, biochar plays an important role in the carbon utilization and non- $\mathrm{CO}_{2}$ greenhouse gases emission reduction [104]. However, the research on increasing greenhouse gas emissions by biochar has also been reported, i.e., under specific conditions, the application of biochar can promote the emissions of $\mathrm{CO}_{2}$ [120], $\mathrm{N}_{2} \mathrm{O}$ [121], $\mathrm{CH}_{4}$ [122] to a certain extent. For example, although biochar can reduce $\mathrm{CH}_{4}$ emissions, it may also promote $\mathrm{N}_{2} \mathrm{O}$ emissions, and vice versa, and this depends on the diversity of biochar application conditions. Therefore, the emission reduction effect of biochar cannot be reflected in all types of greenhouse gases, and blind application may cause negative effects, so the biochar-greenhouse gas interaction should be considered in the field application of biochar. Meanwhile, other research has indicated that biochar can inhibit the efficacy of soil pesticides and their biodegradation effects [123], which makes the ability of agricultural weeding and insecticides unable to achieve the expected effects. The residue of pesticides may be related to the strong adsorption and binding capacity of biochar. Furthermore, although biochar can improve the biological activity of bacteria (e.g., Geobacter, Anaeromyxobacter and Clostridium) [26,96], it may bring about a negative impact on the survival, growth and diversity of, for example, acidophilic earthworm and fungi biological communities [124,125].

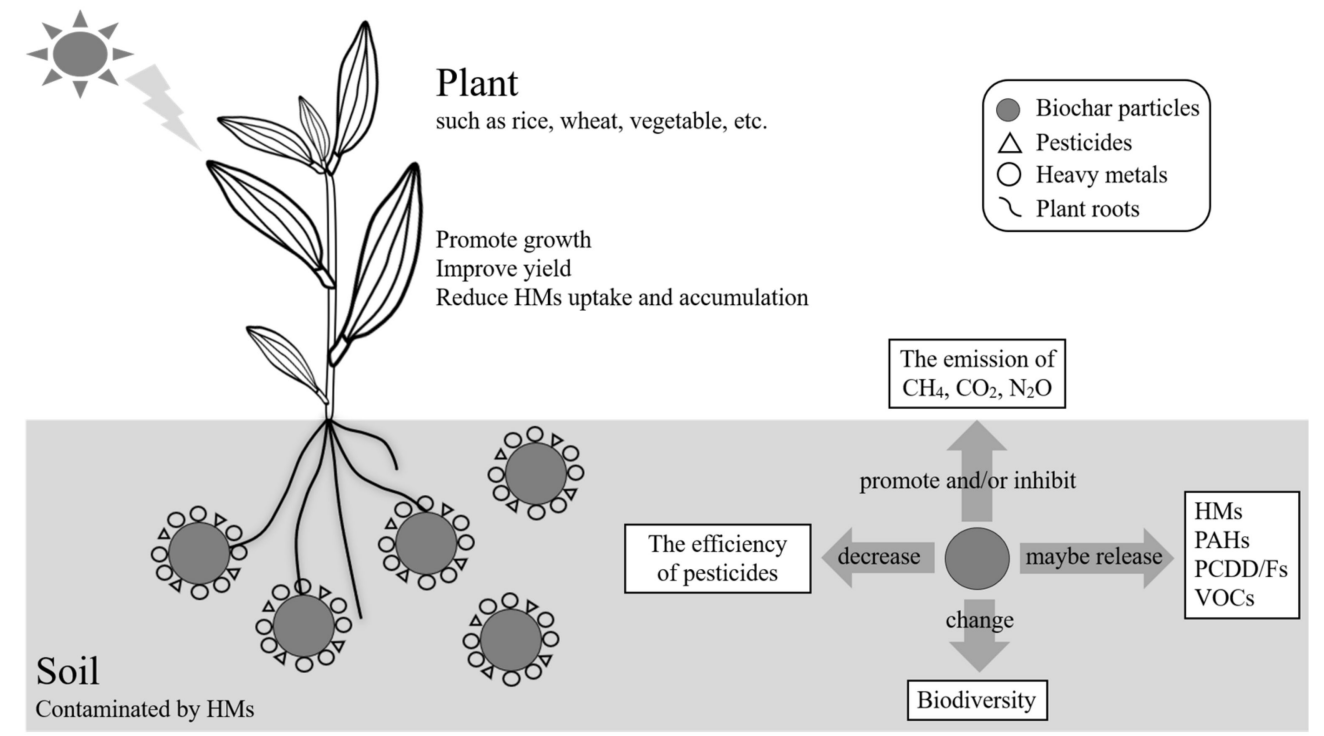

Figure 2. Advantages and disadvantages of biochar in the remediation of soil HM contamination. 


\section{Summary and Future Perspectives}

It is a feasible strategy of green, economic and environmental protection to apply biochar to remediate the HM-contaminated soil. Several thermochemical conversion technologies have been used to prepare biochar, and the performance characteristics of biochar are highly affected by the type of feedstock materials, pyrolysis temperature, and residence time. The immobilization or mobilization mechanisms of HMs includes complexation, reduction, cation exchange, electrostatic attraction and precipitation reactions. The HM uptake and accumulation of plants can be suppressed by biochar through the variation in soil $\mathrm{pH}$ value, DOC content, and other alkaline mineral substances content, and achieve the goal of promoting plant growth, reducing HM bioavailability and improving soil quality in unison.

Modern soil environmental management and remediation technologies are beginning to pay attention to the long-term stability of biochar and the ecological responses of contaminants with the most toxicological fractions. Consequently, in order to meet demand and application-based results, the future application of biochar is predicted as follows:

(1) It is expected that the secondary ecological risks in the process of biochar production will still need to be focused on, i.e., the formation of HMs, VOCs, PCDD/Fs and PAHs. These pollutants are essentially derived from biomass, so it is necessary to screen and pretreat raw biomass materials to remove HMs. In addition, we must adjust the pyrolysis temperature, residence time, pyrolysis atmosphere, pressure conditions and other process parameters to minimize the generation of associated pollutants. Furthermore, it is necessary to establish and perfect the regulatory systems related to the application of biochar in practical engineering.

(2) With the passage of time, soil components will occur varying degrees of physicochemical and biochemical changes, including the properties of biochar (aged biochar) in the meantime. Although the research on soil HM immobilization by biochar has developed to laboratory pot experiments and short-term field trials, the ultimate goal is to extend it to large-scale engineering applications. Hence, carrying out long-term positioning tests in different types of HM-contaminated soil must be conducted, so as to further verify the long-term stability of biochar and its long-term effects on soil environment (such as aggregation, surface potential and density magnitude), and lastly to ensure the quality and safety of agricultural land.

(3) Biochar cannot completely remediate the heavy metals contaminated soil. Therefore, in order to improve the remediation/improvement effects of multi-heavy metals contaminated soil, the multifunctional biochar materials (e.g., biochar inoculated with microorganisms and biochar modified by chemicals and minerals) should be gradually put on the stage of engineering application.

(4) The advantages and disadvantages between the economic cost (production) and benefit value (application) of biochar need to be carefully measured. In order to enhance economic availability, easier production processes and cheaper sources of raw biomass materials need to be discovered, which could provide a platform for improving production efficiency and reducing economic burdens, i.e., to achieve the purpose of commercial practicality.

Author Contributions: Conceptualization, S.C. and T.C.; methodology, S.C.; software, S.C.; validation, J.H.; W.X. and S.J.; formal analysis, W.X.; investigation, S.C.; resources, T.C.; data curation, S.C.; writing-original draft preparation, S.C.; writing-review and editing, T.C.; visualization, S.J.; supervision, T.C.; project administration, T.C. and B.Y.; funding acquisition, B.Y. All authors have read and agreed to the published version of the manuscript.

Funding: This work was financially supported by the National key research and development plan (2018YFC1802800), the Guangdong provincial science and technology program (2015B020237003), the Provincial Science and Technology Plan Project of Guangdong Province, Shao Guan (2018SG00118), and the Guangdong Provincial Key Laboratory of Chemical Pollution and Environmental Safety (2019B030301008).

Acknowledgments: The authors are very grateful to the anonymous reviewers for their revising suggestions.

Conflicts of Interest: The authors declare no conflict of interest. 


\section{References}

1. Xiao, R.; Wang, S.; Li, R.H.; Wang, J.J.; Zhang, Z.Q. Soil heavy metal contamination and health risks associated with artisanal gold mining in Tongguan, Shaanxi, China. Ecotoxicol. Environ. Saf. 2017, 141, 17-24. [CrossRef]

2. Liu, J.; Zhang, X.H.; Henry, T.; Wang, D.Q.; Zhu, Y.N. Heavy metal contamination and risk assessment in water, paddy soil, and rice around an electroplating plant. Environ. Sci. Pollut. Res. 2011, 18, 1623-1632. [CrossRef]

3. Udosen, E.; Akpan, E.; Sam, S. Levels of some heavy Metals in Cocoyam (Colocasia esculentum) grown on Soil receiving Effluent from a Paint Industry. J. Appl. Sci. Environ. Manag. 2016, 20, 215-218. [CrossRef]

4. Kaya, M. Recovery of metals and nonmetals from electronic waste by physical and chemical recycling processes. Waste Manag. 2016, 57, 64-90. [CrossRef]

5. Rattan, R.; Datta, S.; Chhonkar, P.; Suribabu, K.; Singh, A. Long-term impact of irrigation with sewage effluents on heavy metal content in soils, crops and groundwater-A case study. Agric. Ecosyst. Environ. 2005, 109, 310-322. [CrossRef]

6. Gimeno-García, E.; Andreu, V.; Boluda, R. Heavy metals incidence in the application of inorganic fertilizers and pesticides to rice farming soils. Environ. Pollut. 1996, 92, 19-25. [CrossRef]

7. Yang, Q.Q.; Li, Z.Y.; Lu, X.N.; Duan, Q.N.; Huang, L.; Bi, J. A review of soil heavy metal pollution from industrial and agricultural regions in China: Pollution and risk assessment. Sci. Total Environ. 2018, 642, 690-700. [CrossRef]

8. Mahar, A.; Wang, P.; Ali, A.; Awasthi, M.K.; Lahori, A.H.; Wang, Q.; Li, R.; Zhang, Z. Challenges and opportunities in the phytoremediation of heavy metals contaminated soils: A review. Ecotoxicol. Environ. Saf. 2016, 126, 111-121. [CrossRef]

9. Ministry of Environmental Protection of China. National Soil Pollution Survey Bulletin. 2014. Available online: http://www.mee.gov.cn/gkml/sthjbgw/qt/201404/t20140417_270670.htm (accessed on 16 June 2020).

10. Zheng, S.N.; Wang, Q.; Yuan, Y.Z.; Sun, W.M. Human health risk assessment of heavy metals in soil and food crops in the Pearl River Delta urban agglomeration of China. Food Chem. 2020, 316, 126213. [CrossRef]

11. He, Y.; Li, B.B.; Zhang, K.N.; Li, Z.; Chen, Y.G.; Ye, W.M. Experimental and numerical study on heavy metal contaminant migration and retention behavior of engineered barrier in tailings pond. Environ. Pollut. 2019, 252, 1010-1018. [CrossRef]

12. Wu, H.W.; Liu, Q.Y.; Ma, J.; Liu, L.L.; Qu, Y.J.; Gong, Y.W.; Yang, S.H.; Luo, T. Heavy Metal(loids) in typical Chinese tobacco-growing soils: Concentrations, influence factors and potential health risks. Chemosphere 2020, 245, 125591. [CrossRef]

13. Dhaliwal, S.S.; Singh, J.; Taneja, P.K.; Mandal, A. Remediation techniques for removal of heavy metals from the soil contaminated through different sources: A review. Environ. Sci. Pollut. Res. 2019, 27, 1-15. [CrossRef]

14. Lahori, A.H.; Guo, Z.Y.; Zhang, Z.Q.; Li, R.H.; Mahar, A.; Awasthi, M.K.; Shen, F.; Sial, T.A.; Kumbhar, F.; Wang, P. Use of biochar as an amendment for remediation of heavy metal-contaminated soils: Prospects and challenges. Pedosphere 2017, 27, 991-1014. [CrossRef]

15. Karna, R.R.; Luxton, T.; Bronstein, K.E.; Hoponick Redmon, J.; Scheckel, K.G. State of the science review: Potential for beneficial use of waste by-products for in situ remediation of metal-contaminated soil and sediment. Crit. Rev. Environ. Sci. Technol. 2017, 47, 65-129. [CrossRef]

16. Bolan, N.; Kunhikrishnan, A.; Thangarajan, R.; Kumpiene, J.; Park, J.; Makino, T.; Kirkham, M.B.; Scheckel, K. Remediation of heavy metal(loid)s contaminated soils-to mobilize or to immobilize? J. Hazard. Mater. 2014, 266, 141-166. [CrossRef]

17. Palansooriya, K.N.; Shaheen, S.M.; Chen, S.S.; Tsang, D.C.W.; Hashimoto, Y.; Hou, D.; Bolan, N.S.; Rinklebe, J.; Ok, Y.S. Soil amendments for immobilization of potentially toxic elements in contaminated soils: A critical review. Environ. Int. 2020, 134, 105046. [CrossRef]

18. Li, H.B.; Dong, X.L.; Silva, E.B.D.; Oliveira, L.M.D.; Chen, Y.S.; Ma, L.Q. Mechanisms of metal sorption by biochars: Biochar characteristics and modifications. Chemosphere 2017, 178, 466-478. [CrossRef]

19. Tan, X.F.; Liu, Y.G.; Zeng, G.M.; Wang, X.; Hu, X.J.; Gu, Y.L.; Yang, Z.Z. Application of biochar for the removal of pollutants from aqueous solutions. Chemosphere 2015, 125, 70-85. [CrossRef]

20. Martins, G.C.; Penido, E.S.; Alvarenga, I.F.S.; Teodoro, J.C.; Bianchi, M.L.; Guilherme, L.R.G. Amending potential of organic and industrial by-products applied to heavy metal-rich mining soils. Ecotoxicol. Environ. Saf. 2018, 162, 581-590. [CrossRef] 
21. Bashir, S.; Hussain, Q.; Akmal, M.; Riaz, M.; Hu, H.; Ijaz, S.S.; Iqbal, M.; Abro, S.; Mehmood, S.; Ahmad, M. Sugarcane bagasse-derived biochar reduces the cadmium and chromium bioavailability to mash bean and enhances the microbial activity in contaminated soil. J. Soils Sediments 2017, 18, 874-886. [CrossRef]

22. Moore, F.; González, M.E.; Khan, N.; Curaqueo, G.; Sanchez-Monedero, M.; Rilling, J.; Morales, E.; Panichini, M.; Mutis, A.; Jorquera, M. Copper immobilization by biochar and microbial community abundance in metal-contaminated soils. Sci. Total Environ. 2018, 616, 960-969. [CrossRef]

23. Yu, Z.H.; Qiu, W.W.; Wang, F.; Lei, M.; Wang, D.; Song, Z.G. Effects of manganese oxide-modified biochar composites on arsenic speciation and accumulation in an indica rice (Oryza sativa L.) cultivar. Chemosphere 2017, 168, 341-349. [CrossRef] [PubMed]

24. Nie, C.L.; Yang, X.; Niazi, N.K.; Xu, X.Y.; Wen, Y.H.; Rinklebe, J.; Ok, Y.S.; Xu, S.; Wang, H.L. Impact of sugarcane bagasse-derived biochar on heavy metal availability and microbial activity: A field study. Chemosphere 2018, 200, 274-282. [CrossRef]

25. Ahmad, M.; Ok, Y.S.; Kim, B.Y.; Ahn, J.H.; Lee, Y.H.; Zhang, M.; Moon, D.H.; Al-Wabel, M.I.; Lee, S.S. Impact of soybean stover-and pine needle-derived biochars on $\mathrm{Pb}$ and As mobility, microbial community, and carbon stability in a contaminated agricultural soil. J. Environ. Manag. 2016, 166, 131-139. [CrossRef]

26. Wang, N.; Xue, X.M.; Juhasz, A.L.; Chang, Z.Z.; Li, H.B. Biochar increases arsenic release from an anaerobic paddy soil due to enhanced microbial reduction of iron and arsenic. Environ. Pollut. 2017, 220, 514-522. [CrossRef]

27. Choppala, G.; Bolan, N.; Kunhikrishnan, A.; Bush, R. Differential effect of biochar upon reduction-induced mobility and bioavailability of arsenate and chromate. Chemosphere 2016, 144, 374-381. [CrossRef]

28. Xing, Y.; Wang, J.X.; Xia, J.C.; Liu, Z.M.; Zhang, Y.H.; Du, Y.; Wei, W.L. A pilot study on using biochars as sustainable amendments to inhibit rice uptake of $\mathrm{Hg}$ from a historically polluted soil in a Karst region of China. Ecotoxicol. Environ. Saf. 2019, 170, 18-24. [CrossRef]

29. Zhang, M.; Shan, S.D.; Chen, Y.G.; Wang, F.; Yang, D.Y.; Ren, J.K.; Lu, H.Y.; Ping, L.F.; Chai, Y.J. Biochar reduces cadmium accumulation in rice grains in a tungsten mining area-field experiment: Effects of biochar type and dosage, rice variety, and pollution level. Environ. Geochem. Health. 2019, 41, 43-52. [CrossRef]

30. Rechberger, M.V.; Kloss, S.; Wang, S.L.; Lehmann, J.; Rennhofer, H.; Ottner, F.; Wriessnig, K.; Daudin, G.; Lichtenegger, H.; Soja, G. Enhanced $\mathrm{Cu}$ and $\mathrm{Cd}$ sorption after soil aging of woodchip-derived biochar: What were the driving factors? Chemosphere 2019, 216, 463-471. [CrossRef]

31. Wang, A.O.; Ptacek, C.J.; Blowes, D.W.; Gibson, B.D.; Landis, R.C.; Dyer, J.A.; Ma, J. Application of hardwood biochar as a reactive capping mat to stabilize mercury derived from contaminated floodplain soil and riverbank sediments. Sci. Total Environ. 2019, 652, 549-561. [CrossRef]

32. Wang, S.S.; Gao, B.; Zimmerman, A.R.; Li, Y.C.; Ma, L.; Harris, W.G.; Migliaccio, K.W. Removal of arsenic by magnetic biochar prepared from pinewood and natural hematite. Bioresour. Technol. 2015, 175, 391-395. [CrossRef]

33. Li, B.; Yang, L.; Wang, C.Q.; Zhang, Q.P.; Liu, Q.C.; Li, Y.D.; Xiao, R. Adsorption of Cd(II) from aqueous solutions by rape straw biochar derived from different modification processes. Chemosphere 2017, 175, 332-340. [CrossRef]

34. Shen, Z.T.; Hou, D.Y.; Jin, F.; Shi, J.X.; Fan, X.L.; Tsang, D.C.; Alessi, D.S. Effect of production temperature on lead removal mechanisms by rice straw biochars. Sci. Total Environ. 2019, 655, 751-758. [CrossRef]

35. Cao, X.D.; Harris, W. Properties of dairy-manure-derived biochar pertinent to its potential use in remediation. Bioresour. Technol. 2010, 101, 5222-5228. [CrossRef]

36. Meier, S.; Curaqueo, G.; Khan, N.; Bolan, N.; Cea, M.; Eugenia, G.M.; Cornejo, P.; Ok, Y.S.; Borie, F. Chicken-manure-derived biochar reduced bioavailability of copper in a contaminated soil. J. Soils Sediments 2017, 17, 741-750. [CrossRef]

37. Sahin, O.; Taskin, M.; Kaya, E.; Atakol, O.; Emir, E.; Inal, A.; Gunes, A. Effect of acid modification of biochar on nutrient availability and maize growth in a calcareous soil. Soil Use Manag. 2017, 33, 447-456. [CrossRef]

38. Wang, Y.; Lin, Y.X.; Chiu, P.C.; Imhoff, P.T.; Guo, M.X. Phosphorus release behaviors of poultry litter biochar as a soil amendment. Sci. Total Environ. 2015, 512, 454-463. [CrossRef]

39. Ho, S.H.; Yang, Z.K.; Nagarajan, D.; Chang, J.S.; Ren, N.Q. High-efficiency removal of lead from wastewater by biochar derived from anaerobic digestion sludge. Bioresour. Technol. 2017, 246, 142-149. [CrossRef] 
40. Jin, J.W.; Li, Y.A.; Zhang, J.Y.; Wu, S.C.; Cao, Y.C.; Liang, P.; Zhang, J.; Wong, M.H.; Wang, M.Y.; Shan, S.D. Influence of pyrolysis temperature on properties and environmental safety of heavy metals in biochars derived from municipal sewage sludge. J. Hazard. Mater. 2016, 320, 417-426. [CrossRef]

41. Zhang, J.; Wu, S.C.; Xu, Z.T.; Wang, M.Y.; Man, Y.B.; Christie, P.; Liang, P.; Shan, S.D.; Wong, M.H. The role of sewage sludge biochar in methylmercury formation and accumulation in rice. Chemosphere 2019, 218, 527-533. [CrossRef]

42. Rangabhashiyam, S.; Balasubramanian, P. The potential of lignocellulosic biomass precursors for biochar production: Performance, mechanism and wastewater application-A review. Ind. Crop. Prod. 2019, $128,405-423$.

43. Zhang, Z.K.; Zhu, Z.Y.; Shen, B.X.; Liu, L.N. Insights into biochar and hydrochar production and applications: A review. Energy 2019, 171, 581-598. [CrossRef]

44. Shaheen, S.M.; Niazi, N.K.; Hassan, N.E.; Bibi, I.; Wang, H.L.; Tsang, D.C.; Ok, Y.S.; Bolan, N.; Rinklebe, J. Wood-based biochar for the removal of potentially toxic elements in water and wastewater: A critical review. Int. Mater. Rev. 2019, 64, 216-247. [CrossRef]

45. Ahmad, M.; Rajapaksha, A.U.; Lim, J.E.; Zhang, M.; Bolan, N.; Mohan, D.; Vithanage, M.; Lee, S.S.; Ok, Y.S. Biochar as a sorbent for contaminant management in soil and water: A review. Chemosphere 2014, 99, $19-33$. [CrossRef] [PubMed]

46. Tripathi, M.; Sahu, J.N.; Ganesan, P. Effect of process parameters on production of biochar from biomass waste through pyrolysis: A review. Renew. Sustain. Energy Rev. 2016, 55, 467-481. [CrossRef]

47. Qambrani, N.A.; Rahman, M.M.; Won, S.; Shim, S.; Ra, C. Biochar properties and eco-friendly applications for climate change mitigation, waste management, and wastewater treatment: A review. Renew. Sustain. Energy Rev. 2017, 79, 255-273. [CrossRef]

48. Kumar, A.; Saini, K.; Bhaskar, T. Advances in design strategies for preparation of biochar based catalytic system for production of high value chemicals. Bioresour. Technol. 2019, 299, 122564. [CrossRef]

49. Manyà, J.J. Pyrolysis for biochar purposes: A review to establish current knowledge gaps and research needs. Environ. Sci. Technol. 2012, 46, 7939-7954. [CrossRef]

50. Xie, T.; Reddy, K.R.; Wang, C.W.; Yargicoglu, E.; Spokas, K. Characteristics and applications of biochar for environmental remediation: A review. Crit. Rev. Environ. Sci. Technol. 2015, 45, 939-969. [CrossRef]

51. Kambo, H.S.; Dutta, A. A comparative review of biochar and hydrochar in terms of production, physico-chemical properties and applications. Renew. Sustain. Energy Rev. 2015, 45, 359-378. [CrossRef]

52. Liu, W.J.; Jiang, H.; Yu, H.Q. Development of biochar-based functional materials: Toward a sustainable platform carbon material. Chem. Rev. 2015, 115, 12251-12285. [CrossRef] [PubMed]

53. Cheng, F.; Li, X.W. Preparation and application of biochar-based catalysts for biofuel production. Catalysts 2018, 8, 346. [CrossRef]

54. Gul, S.; Whalen, J.K.; Thomas, B.W.; Sachdeva, V.; Deng, H. Physico-chemical properties and microbial responses in biochar-amended soils: Mechanisms and future directions. Agric. Ecosyst. Environ. 2015, 206, 46-59. [CrossRef]

55. Singh, B.; Singh, B.P.; Cowie, A.L. Characterisation and evaluation of biochars for their application as a soil amendment. Soil Res. 2010, 48, 516-525. [CrossRef]

56. Cantrell, K.B.; Hunt, P.G.; Uchimiya, M.; Novak, J.M.; Ro, K.S. Impact of pyrolysis temperature and manure source on physicochemical characteristics of biochar. Bioresour. Technol. 2012, 107, 419-428. [CrossRef]

57. Chen, Z.M.; Chen, B.L.; Chiou, C.T. Fast and slow rates of naphthalene sorption to biochars produced at different temperatures. Environ. Sci. Technol. 2012, 46, 11104-11111. [CrossRef]

58. Keiluweit, M.; Nico, P.S.; Johnson, M.G.; Kleber, M. Dynamic molecular structure of plant biomass-derived black carbon (biochar). Environ. Sci. Technol. 2010, 44, 1247-1253. [CrossRef]

59. Suliman, W.; Harsh, J.B.; Abu-Lail, N.I.; Fortuna, A.M.; Dallmeyer, I.; Garcia-Perez, M. Influence of feedstock source and pyrolysis temperature on biochar bulk and surface properties. Biomass Bioenergy 2016, 84, 37-48. [CrossRef]

60. Hossain, M.K.; Strezov, V.; Chan, K.Y.; Ziolkowski, A.; Nelson, P.F. Influence of pyrolysis temperature on production and nutrient properties of wastewater sludge biochar. J. Environ. Manag. 2011, 92, 223-228. [CrossRef] 
61. Hussain, M.; Farooq, M.; Nawaz, A.; Al-Sadi, A.M.; Solaiman, Z.M.; Alghamdi, S.S.; Ammara, U.; Ok, Y.S.; Siddique, K.H. Biochar for crop production: Potential benefits and risks. J. Soils Sediments 2017, 17, 685-716. [CrossRef]

62. Yuan, H.R.; Lu, T.; Wang, Y.Z.; Chen, Y.; Lei, T.Z. Sewage sludge biochar: Nutrient composition and its effect on the leaching of soil nutrients. Geoderma 2016, 267, 17-23. [CrossRef]

63. Peng, X.; Ye, L.L.; Wang, C.H.; Zhou, H.; Sun, B. Temperature-and duration-dependent rice straw-derived biochar: Characteristics and its effects on soil properties of an Ultisol in southern China. Soil Tillage Res. 2011, 112, 159-166. [CrossRef]

64. Wu, W.X.; Yang, M.; Feng, Q.B.; McGrouther, K.; Wang, H.L.; Lu, H.H.; Chen, Y.X. Chemical characterization of rice straw-derived biochar for soil amendment. Biomass Bioenergy 2012, 47, 268-276. [CrossRef]

65. Zhao, B.; O'Connor, D.; Zhang, J.L.; Peng, T.Y.; Shen, Z.T.; Tsang, D.C.; Hou, D.Y. Effect of pyrolysis temperature, heating rate, and residence time on rapeseed stem derived biochar. J. Clean. Prod. 2018, 174, 977-987. [CrossRef]

66. Jindo, K.; Mizumoto, H.; Sawada, Y.; Sanchez-Monedero, M.A.; Sonoki, T. Physical and chemical characterization of biochars derived from different agricultural residues. Biogeosciences 2014, 11, 6613-6621. [CrossRef]

67. Leng, L.J.; Huang, H.J. An overview of the effect of pyrolysis process parameters on biochar stability. Bioresour. Technol. 2018, 270, 627-642. [CrossRef] [PubMed]

68. Wang, Z.Y.; Liu, G.C.; Zheng, H.; Li, F.M.; Ngo, H.H.; Guo, W.S.; Liu, C.; Chen, L.; Xing, B.S. Investigating the mechanisms of biochar's removal of lead from solution. Bioresour. Technol. 2015, 177, 308-317. [CrossRef] [PubMed]

69. Yaashikaa, P.R.; Kumar, P.S.; Varjani, S.J.; Saravanan, A. Advances in production and application of biochar from lignocellulosic feedstocks for remediation of environmental pollutants. Bioresour. Technol. 2019, 292, 122030. [CrossRef]

70. Ding, W.C.; Dong, X.L.; Ime, I.M.; Gao, B.; Ma, L.Q. Pyrolytic temperatures impact lead sorption mechanisms by bagasse biochars. Chemosphere 2014, 105, 68-74. [CrossRef]

71. Yang, F.; Zhao, L.; Gao, B.; Xu, X.Y.; Cao, X.D. The interfacial behavior between biochar and soil minerals and its effect on biochar stability. Environ. Sci. Technol. 2016, 50, 2264-2271. [CrossRef]

72. Rajapaksha, A.U.; Chen, S.S.; Tsang, D.C.; Zhang, M.; Vithanage, M.; Mandal, S.; Gao, B.; Bolan, N.S.; Ok, Y.S. Engineered/designer biochar for contaminant removal/immobilization from soil and water: Potential and implication of biochar modification. Chemosphere 2016, 148, 276-291. [CrossRef]

73. Weber, K.; Quicker, P. Properties of biochar. Fuel 2018, 217, 240-261. [CrossRef]

74. Lee, J.W.; Kidder, M.; Evans, B.R.; Paik, S.; Buchanan Iii, A.; Garten, C.T.; Brown, R.C. Characterization of biochars produced from cornstovers for soil amendment. Environ. Sci. Technol. 2010, 44, 7970-7974. [CrossRef] [PubMed]

75. Yuan, H.R.; Lu, T.; Huang, H.Y.; Zhao, D.D.; Kobayashi, N.; Chen, Y. Influence of pyrolysis temperature on physical and chemical properties of biochar made from sewage sludge. J. Anal. Appl. Pyrolysis. 2015, 112, 284-289. [CrossRef]

76. Heitkötter, J.; Marschner, B. Interactive effects of biochar ageing in soils related to feedstock, pyrolysis temperature, and historic charcoal production. Geoderma 2015, 245, 56-64. [CrossRef]

77. Kavitha, B.; Reddy, P.V.L.; Kim, B.; Lee, S.S.; Pandey, S.K.; Kim, K.H. Benefits and limitations of biochar amendment in agricultural soils: A review. J. Environ. Manag. 2018, 227, 146-154. [CrossRef]

78. Gai, X.P.; Wang, H.Y.; Liu, J.; Zhai, L.M.; Liu, S.; Ren, T.Z.; Liu, H.B. Effects of feedstock and pyrolysis temperature on biochar adsorption of ammonium and nitrate. PLoS ONE 2014, 9, e113888. [CrossRef]

79. Maroušek, J.; Vochozka, M.; Plachý, J.; Žák, J. Glory and misery of biochar. Clean Technol. Environ. Policy 2017, 19, 311-317. [CrossRef]

80. Yuan, J.H.; Xu, R.K.; Zhang, H. The forms of alkalis in the biochar produced from crop residues at different temperatures. Bioresour. Technol. 2011, 102, 3488-3497. [CrossRef]

81. Fidel, R.B.; Laird, D.A.; Thompson, M.L.; Lawrinenko, M. Characterization and quantification of biochar alkalinity. Chemosphere 2017, 167, 367-373. [CrossRef]

82. Tag, A.T.; Duman, G.; Ucar, S.; Yanik, J. Effects of feedstock type and pyrolysis temperature on potential applications of biochar. J. Anal. Appl. Pyrolysis. 2016, 120, 200-206. [CrossRef] 
83. Magdziarz, A.; Wilk, M.; Wadrzyk, M. Pyrolysis of hydrochar derived from biomass-Experimental investigation. Fuel 2020, 267, 117246. [CrossRef]

84. Gronwald, M.; Helfrich, M.; Don, A.; Fuß, R.; Well, R.; Flessa, H. Application of hydrochar and pyrochar to manure is not effective for mitigation of ammonia emissions from cattle slurry and poultry manure. Biol. Fertil. Soils. 2018, 54, 451-465. [CrossRef]

85. Cui, X.Q.; Lu, M.; Khan, M.B.; Lai, C.Y.; Yang, X.E.; He, Z.L.; Chen, G.Y.; Yan, B.B. Hydrothermal carbonization of different wetland biomass wastes: Phosphorus reclamation and hydrochar production. Waste Manag. 2020, 102, 106-113. [CrossRef]

86. Liu, X.M.; Zhai, Y.B.; Li, S.H.; Wang, B.; Wang, T.F.; Liu, Y.L.; Qiu, Z.Z.; Li, C.T. Hydrothermal carbonization of sewage sludge: Effect of feed-water $\mathrm{pH}$ on hydrochar's physicochemical properties, organic component and thermal behavior. J. Hazard. Mater. 2020, 388, 122084. [CrossRef]

87. Garlapalli, R.K.; Wirth, B.; Reza, M.T. Pyrolysis of hydrochar from digestate: Effect of hydrothermal carbonization and pyrolysis temperatures on pyrochar formation. Bioresour. Technol. 2016, 220, 168-174. [CrossRef]

88. Wang, M.M.; Zhu, Y.; Cheng, L.R.; Andserson, B.; Zhao, X.H.; Wang, D.Y.; Ding, A.Z. Review on utilization of biochar for metal-contaminated soil and sediment remediation. J. Environ. Sci. 2018, 63, 156-173. [CrossRef]

89. Xu, M.; Wu, J.; Luo, L.; Yang, G.; Zhang, X.H.; Peng, H.; Yu, X.Y.; Wang, L.L. The factors affecting biochar application in restoring heavy metal-polluted soil and its potential applications. Chem. Ecol. 2018, 34, 177-197. [CrossRef]

90. Gonzaga, M.I.S.; Matias, M.I.D.A.S.; Andrade, K.R.; Jesus, A.N.D.; Cunha, G.D.C.; Andrade, R.S.D.; Santos, J.C.D.J. Aged biochar changed copper availability and distribution among soil fractions and influenced corn seed germination in a copper-contaminated soil. Chemosphere 2020, 240, 124828. [CrossRef]

91. Park, J.H.; Choppala, G.K.; Bolan, N.S.; Chung, J.W.; Chuasavathi, T. Biochar reduces the bioavailability and phytotoxicity of heavy metals. Plant Soil 2011, 348, 439. [CrossRef]

92. Gonzaga, M.I.S.; Mackowiak, C.; de Almeida, A.Q.; Wisniewski Jr, A.; de Souza, D.F.; da Silva Lima, I.; de Jesus, A.N. Assessing biochar applications and repeated Brassica juncea L. production cycles to remediate Cu contaminated soil. Chemosphere 2018, 201, 278-285. [CrossRef] [PubMed]

93. Zhang, C.; Shan, B.Q.; Zhu, Y.Y.; Tang, W.Z. Remediation effectiveness of Phyllostachys pubescens biochar in reducing the bioavailability and bioaccumulation of metals in sediments. Environ. Pollut. 2018, 242, 1768-1776. [CrossRef] [PubMed]

94. Yin, D.X.; Wang, X.; Peng, B.; Tan, C.Y.; Ma, L.Q. Effect of biochar and Fe-biochar on Cd and As mobility and transfer in soil-rice system. Chemosphere 2017, 186, 928-937. [CrossRef] [PubMed]

95. Kim, H.B.; Kim, S.H.; Jeon, E.K.; Kim, D.H.; Tsang, D.C.; Alessi, D.S.; Kwon, E.E.; Baek, K. Effect of dissolved organic carbon from sludge, Rice straw and spent coffee ground biochar on the mobility of arsenic in soil. Sci. Total Environ. 2018, 636, 1241-1248. [CrossRef]

96. Qiao, J.T.; Li, X.M.; Li, F.B. Roles of different active metal-reducing bacteria in arsenic release from arsenic-contaminated paddy soil amended with biochar. J. Hazard. Mater. 2018, 344, 958-967. [CrossRef]

97. Li, G.; Khan, S.; Ibrahim, M.; Sun, T.R.; Tang, J.F.; Cotner, J.B.; Xu, Y.Y. Biochars induced modification of dissolved organic matter (DOM) in soil and its impact on mobility and bioaccumulation of arsenic and cadmium. J. Hazard. Mater. 2018, 348, 100-108. [CrossRef] [PubMed]

98. Bian, R.J.; Joseph, S.; Cui, L.Q.; Pan, G.X.; Li, L.Q.; Liu, X.Y.; Zhang, A.F.; Rutlidge, H.; Wong, S.; Chia, C. A three-year experiment confirms continuous immobilization of cadmium and lead in contaminated paddy field with biochar amendment. J. Hazard. Mater. 2014, 272, 121-128. [CrossRef]

99. Gao, X.; Peng, Y.T.; Zhou, Y.Y.; Adeel, M.; Chen, Q. Effects of magnesium ferrite biochar on the cadmium passivation in acidic soil and bioavailability for packoi (Brassica chinensis L.). J. Environ. Manag. 2019, 251, 109610. [CrossRef]

100. Igalavithana, A.D.; Kwon, E.E.; Vithanage, M.; Rinklebe, J.; Moon, D.H.; Meers, E.; Tsang, D.C.; Ok, Y.S. Soil lead immobilization by biochars in short-term laboratory incubation studies. Environ. Int. 2019, 127, 190-198. [CrossRef]

101. Huang, D.L.; Deng, R.; Wan, J.; Zeng, G.M.; Xue, W.J.; Wen, X.F.; Zhou, C.Y.; Hu, L.; Liu, X.G.; Xu, P. Remediation of lead-contaminated sediment by biochar-supported nano-chlorapatite: Accompanied with the change of available phosphorus and organic matters. J. Hazard. Mater. 2018, 348, 109-116. [CrossRef] 
102. O'Connor, D.; Peng, T.Y.; Li, G.H.; Wang, S.X.; Duan, L.; Mulder, J.; Cornelissen, G.; Cheng, Z.L.; Yang, S.; Hou, D.Y. Sulfur-modified rice husk biochar: A green method for the remediation of mercury contaminated soil. Sci. Total Environ. 2018, 621, 819-826. [CrossRef] [PubMed]

103. Herath, I.; Iqbal, M.; Al-Wabel, M.I.; Abduljabbar, A.; Ahmad, M.; Usman, A.R.; Ok, Y.S.; Vithanage, M. Bioenergy-derived waste biochar for reducing mobility, bioavailability, and phytotoxicity of chromium in anthropized tannery soil. J. Soils Sediments 2017, 17, 731-740. [CrossRef]

104. Zhou, J.M.; Chen, H.L.; Tao, Y.L.; Thring, R.W.; Mao, J.L. Biochar amendment of chromium-polluted paddy soil suppresses greenhouse gas emissions and decreases chromium uptake by rice grain. J. Soils Sediments 2019, 19, 1756-1766. [CrossRef]

105. Lyu, H.H.; Zhao, H.; Tang, J.C.; Gong, Y.Y.; Huang, Y.; Wu, Q.H.; Gao, B. Immobilization of hexavalent chromium in contaminated soils using biochar supported nanoscale iron sulfide composite. Chemosphere 2017, 194, 360-369. [CrossRef] [PubMed]

106. Wagner, A.; Kaupenjohann, M. Biochar addition enhanced growth of D actylis glomerata L. and immobilized $\mathrm{Zn}$ and $\mathrm{Cd}$ but mobilized $\mathrm{Cu}$ and $\mathrm{Pb}$ on a former sewage field soil. Eur. J. Soil Sci. 2015, 66, 505-515. [CrossRef]

107. Qian, T.T.; Wu, P.; Qin, Q.Y.; Huang, Y.N.; Wang, Y.J.; Zhou, D.M. Screening of wheat straw biochars for the remediation of soils polluted with Zn (II) and Cd (II). J. Hazard. Mater. 2019, 362, 311-317. [CrossRef]

108. Zhang, H.; Feng, X.B.; Larssen, T.; Shang, L.H.; Li, P. Bioaccumulation of methylmercury versus inorganic mercury in rice (Oryza sativa L.) grain. Environ. Sci. Technol. 2010, 44, 4499-4504. [CrossRef]

109. Xia, S.P.; Song, Z.L.; Jeyakumar, P.; Bolan, N.; Wang, H.L. Characteristics and applications of biochar for remediating $\mathrm{Cr}(\mathrm{VI})$-contaminated soils and wastewater. Environ. Geochem. Health 2019, 1-25. [CrossRef]

110. Xu, Z.B.; Xu, X.Y.; Tao, X.Y.; Yao, C.B.; Tsang, D.C.; Cao, X.D. Interaction with low molecular weight organic acids affects the electron shuttling of biochar for Cr (VI) reduction. J. Hazard. Mater. 2019, 378, 120705. [CrossRef]

111. Mandal, S.; Sarkar, B.; Bolan, N.; Ok, Y.S.; Naidu, R. Enhancement of chromate reduction in soils by surface modified biochar. J. Environ. Manag. 2017, 186, 277-284. [CrossRef]

112. Ni, J.J.; Bordoloi, S.; Shao, W.; Garg, A.; Xu, G.Z.; Sarmah, A.K. Two-year evaluation of hydraulic properties of biochar-amended vegetated soil for application in landfill cover system. Sci. Total Environ. 2020, 712, 136486. [CrossRef] [PubMed]

113. Zheng, R.L.; Chen, Z.; Cai, C.; Tie, B.Q.; Liu, X.L.; Reid, B.J.; Huang, Q.; Lei, M.; Sun, G.X.; Baltrènaitè, E. Mitigating heavy metal accumulation into rice (Oryza sativa L.) using biochar amendment-A field experiment in Hunan, China. Environ. Sci. Pollut. Res. 2015, 22, 11097-11108. [CrossRef] [PubMed]

114. Glaser, B.; Wiedner, K.; Seelig, S.; Schmidt, H.P.; Gerber, H. Biochar organic fertilizers from natural resources as substitute for mineral fertilizers. Agron. Sustain. Dev. 2015, 35, 667-678. [CrossRef]

115. Xu, P.; Sun, C.X.; Ye, X.Z.; Xiao, W.D.; Zhang, Q.; Wang, Q. The effect of biochar and crop straws on heavy metal bioavailability and plant accumulation in a $\mathrm{Cd}$ and $\mathrm{Pb}$ polluted soil. Ecotoxicol. Environ. Saf. 2016, 132, 94-100. [CrossRef]

116. Xu, Y.G.; Qi, F.J.; Bai, T.X.; Yan, Y.B.; Wu, C.C.; An, Z.R.; Luo, S.; Huang, Z.; Xie, P. A further inquiry into co-pyrolysis of straws with manures for heavy metal immobilization in manure-derived biochars. J. Hazard. Mater. 2019, 38, 120870. [CrossRef]

117. Buss, W.; Mašek, O. High-VOC biochar-Effectiveness of post-treatment measures and potential health risks related to handling and storage. Environ. Sci. Pollut. Res. 2016, 23, 19580-19589. [CrossRef]

118. Zielińska, A.; Oleszczuk, P. Effect of pyrolysis temperatures on freely dissolved polycyclic aromatic hydrocarbon (PAH) concentrations in sewage sludge-derived biochars. Chemosphere 2016, 153, 68-74. [CrossRef]

119. Lyu, H.H.; He, Y.H.; Tang, J.C.; Hecker, M.; Liu, Q.L.; Jones, P.D.; Codling, G.; Giesy, J.P. Effect of pyrolysis temperature on potential toxicity of biochar if applied to the environment. Environ. Pollut. 2016, 218, 1-7. [CrossRef]

120. Yang, X.; Meng, J.; Lan, Y.; Chen, W.F.; Yang, T.X.; Yuan, J.; Liu, S.N.; Han, J. Effects of maize stover and its biochar on soil $\mathrm{CO}_{2}$ emissions and labile organic carbon fractions in Northeast China. Agric. Ecosyst. Environ. 2017, 240, 24-31. [CrossRef] 
121. Liu, J.Y.; Shen, J.L.; Li, Y.; Su, Y.R.; Ge, T.D.; Jones, D.L.; Wu, J.S. Effects of biochar amendment on the net greenhouse gas emission and greenhouse gas intensity in a Chinese double rice cropping system. Eur. J. Soil Biol. 2014, 65, 30-39. [CrossRef]

122. Ribas, A.; Mattana, S.; Llurba, R.; Debouk, H.; Sebastià, M.; Domene, X. Biochar application and summer temperatures reduce $\mathrm{N}_{2} \mathrm{O}$ and enhance $\mathrm{CH}_{4}$ emissions in a Mediterranean agroecosystem: Role of biologically-induced anoxic microsites. Sci. Total Environ. 2019, 685, 1075-1086. [CrossRef] [PubMed]

123. Cheng, H.; Jones, D.L.; Hill, P.; Bastami, M.S. Biochar concomitantly increases simazine sorption in sandy loam soil and lowers its dissipation. Arch. Agron. Soil Sci. 2017, 63, 1082-1092. [CrossRef]

124. Chen, J.H.; Liu, X.Y.; Zheng, J.W.; Zhang, B.; Lu, H.; Chi, Z.Z.; Pan, G.X.; Li, L.Q.; Zheng, J.F.; Zhang, X.H. Biochar soil amendment increased bacterial but decreased fungal gene abundance with shifts in community structure in a slightly acid rice paddy from Southwest China. Appl. Soil Ecol. 2013, 71, 33-44. [CrossRef]

125. Anyanwu, I.N.; Alo, M.N.; Onyekwere, A.M.; Crosse, J.D.; Nworie, O.; Chamba, E.B. Influence of biochar aged in acidic soil on ecosystem engineers and two tropical agricultural plants. Ecotoxicol. Environ. Saf. 2018, 153, 116-126. [CrossRef]

(C) 2020 by the authors. Licensee MDPI, Basel, Switzerland. This article is an open access article distributed under the terms and conditions of the Creative Commons Attribution (CC BY) license (http://creativecommons.org/licenses/by/4.0/). 